\title{
Risk Altındaki Tarihi Bir Bina İçin Uyarlanabilir Yeniden Kullanım Önerisi: Ambar Köyü Kilisesi Örneği**
}

\author{
Necla KAPLAN ${ }^{1 *}$
}

\section{Öz}

Bir kentin imajı olan tarihi yapılar, korunabildiği oranda geçmişi geleceğe taşıyabilen değerli kültür varlıklarıdır. Maalesef, günümüzde plansız yeni yerleşmeler ve hızlı yapılaşmalar toplumun tarihi mimari yapılarının tahrip olmasına ve hatta yok olmasına sebep olmaktadır. Böylesi risk altında görülen yapılar; restore edilerek, sürekli bakım yapılarak ve hatta yeniden işlevlendirilerek daha uzun süre yaşatılabilmektedir. Mardin Il'inde de yok olma riski altında bulunan pek çok yapı mevcuttur. Bu yapılardan bir tanesi de Ambar Köyü Kilisesidir. 6. yüzyıldan kalma kilise, sahip olduğu tarihi değere yakışmayan harabe bir haldedir. Kilise, içinde bulunduğu kötü koşullardan kurtarılması gereken tarihi mimari kültür mirasıdır. Bu bakış açısıyla değerlendirilen yapının korunması ve yeniden işlevlendirilerek kültürel kimliğini sürdürebilmesi sağlanmalıdır. Çalışmada kiliseyi, tarihi ve mimari özellikleriyle tanıtmak, içinde bulunduğu risk unsurlarına değinmek, bunların giderilmesi ve yeniden işlevlendirmesine yönelik öneriler sunmak hedeflenmektedir. Ayrıca yapının mekânsal performansının yöre sakinlerine katkısının, çevre ve kullanıcılar arasındaki tarihi, sosyal, kültürel ve ekonomik getirilerinin ortaya konulması amaçlanmıştır. Bu amaçla yapı yerinde incelenmiş, plan ve fotoğraflarla değerlendirilmiştir.

Anahtar Kelimeler: Ambar Köyü Kilisesi, Yeniden Iş̧levlendirme, Mardin,

\section{The Adaptive Re-use Propasal for a Historic Building at Risk: The Case of Ambar Village Church}

\begin{abstract}
Historic buildings are valuable cultural assets that symbolize the character and structure of the urban image. The more they are preserved, the more they bring the past into the future. However, unplanned new settlements and rapid construction lead to damage and even the destruction of historic buildings. Restoration, preservation, or reconstruction can extend the life of historic buildings at risk. There are a lot of historic architectural structures at the risk of destruction in Mardin/Turkey. One of those buildings is the Church of Ambar Village, which dates back to the sixth century. However, in contrast to its historical value, it is in remains and rubble, waiting for its ultimate demise. The church is a historical and architectural cultural heritage that must be saved from bad conditions. The reuse allows immovable heritage to maintain its cultural identity. The structure evaluated from this point of view should be protected and re-used so that it can maintain its cultural identity. This study aims to introduce the church with its historical and architectural features, take attention to the risk factors it is in, and finally offer suggestions for eliminating the risk situation and re-use of the

\footnotetext{
${ }^{1}$ Mardin Artuklu Üniversitesi, Sanat Tarihi Bölümü, Mardin, Türkiye

Bu makale, 21-23 Aralık 2018 tarihleri arasında IKSAD tarafından Mardin'de düzenlenen "IV. Uluslararası Mardin Kültür Ve Medeniyet Kongresi"nde sunulan ve henüz yayınlanmamış olan "Ambar Köyü Kilisesi'nin Yeniden İşlevlendirilmesi Üzerine Bir Öneri" adlı bildirinin revize edilerek, değişiklik ve eklemelerle yeniden yazıımış halidir. Bu kilise 2018 yılı alan çalışması için Kültür Bakanlığı'ndan alınan izinle başlatılan "Mardin Merkez'deki Hıristiyan Dini Mimarisi" başlıkı kitap çalışması kapsamında incelenmiş ve risk altında olduğu, daha önce akademik bir çalışmaya konu olmadığı tespit edildiği için bu makaleye konu edilmiştir.

* İlgili yazar/Corresponding author: neclakaplan21@hotmail.com

Gönderim Tarihi / Received Date: 14.02.2021

Kabul Tarihi / Accepted Date: 03.08.2021
} 
building. Besides, another aim of the study is to reveal the contribution of the building's spatial performance to the residents and its historical, social, cultural, and economic benefits for people living around the building. For this purpose, the building was examined on-site and evaluated with plans and photographs.

Keywords: The Church of Ambar Village, Re-use, Mardin

\section{Giriş}

Toplumların tarihsel süreç içinde yaşadığı değişim ve dönüşümün en somut tanıkları tarihi eserlerdir. Bu eserlerden mimari yapıların, uzun yıllar ayakta kalabilmeleri büyük bir şanstır. Günümüzde yeni yerleşmeler ve hızlı yapılaşma maalesef, tarihi yapıların tahribine ve yok olmasına sebep olmaktadır. Taşınmaz kültür varlıkları olan bu mimari yapıların korunması tarihi belleğin güçlü tutulması, kültürel aktarım ve sanat ile mimarlık tarihi açısından önem arz etmektedir. Bu nedenle sayıları oldukça az kalan ve risk altındaki tarihi yapıların korunması gerekmektedir.

Son yıllarda, taşınmaz kültür varlıklarının yeni bir işlevsellikle yeniden canlandırılması, geliştirilen "öneri projeler" çerçevesinde çeşitli platformlarda tartışılmaktadır. Toplumların değişen sosyo-ekonomik durumu doğrultusunda ortaya çıkan yeni intiyaçları için; farklı kullanıma sahip yapıların yeniden kullanılabilir hale getirilmesi, eserlerin tarihsel süreklilikle günümüzde yaşatımasını ve gelecek kuşaklara aktarılmasını sağladığı bilinmektedir (Yeşilbaş, 2016, s.199; Birol, 2019, s. 187-188). Nitekim farklı fonksiyonlara sahip tarihi-kültürel yapı türlerinden hanlar (Yeşilbaş, 2014, s. 65-88), medreseler, malikhaneler (Coşkun, 2018, s. 17-32) ${ }^{2}$, sebiller ${ }^{3}$ ve kiliseler (Aydın ve Şahin, 2018, s. 63-75 ${ }^{4}$ ) üzerinden öneri projeleri geliştirilmiş ve bunlardan bir kısmı da hayata geçirilmiştir. Bu tür müdahaleler, yapıların daha uzun süre yaşatılmasını olanaklı kılmaktadır.

Mardin ilinde de yok olma riski altında bulunan pek çok yapı mevcuttur. Bu yapılardan bir tanesi de Ambar Köyü Kilisesi'dir. 6. yüzyıldan kalma olduğu düşünülen kilise, ne yazık ki, yaklaşık 1500 yıllık tarihine yakışmayan bir halde ve yok olmaya terk edilmiş durumdadır. Daha önce monografik bir çalışmaya konu olmamış Ambar Köyü Kilisesi'nin güncel bir çalışmayla tanıtılması, içinde bulunduğu riskli duruma dikkat çekilmesi ve korunmasına yönelik öneriler sunulması amaçlanmıştır. Çalışmada, kilisenin bulunduğu yörenin kısa tarihine ve konumuna, konumunun önemine değinilmiş, yapının tarihi ve mimari özellikleri açıklanmıştır. Daha sonra kilisede tespit edilen hasarlara, bunların nedenlerine ve çözüm önerilerine yer verilmiştir. Nihayetinde çevresiyle organik bağını ortaya koyan ve güncel yaşamla bütünleşen dinamikleri de göz önünde bulundurularak sahip olduğu potansiyel uygun yeniden işlevlendirme önerisi sunulmuştur. Birden fazla fonksiyon içeren işlev önerisi, maddeler halinde sıralanacaktır.

Çalışmada; araştırma, yapı tespiti-yerinde inceleme, görüşme ve gözlem yöntemi kullanılmıştır. Yapının bulunduğu köye belli aralıklarla gidilerek eser, yerinde incelenmiştir. Fotoğrafları çekilmiş, ölçüleri alınmıştır. Yapının üstünde ve çevresinde

\footnotetext{
${ }^{2}$ Coşkun'un (2018, s. 17-32) makalesinde değindiği Astley Castle Örneği üzerinden, risk altındaki tarihi yapıların yeniden işlevlendirilmesi konusunun İngiltere'de 19. yüzyılın sonundan beri önemsenen konulardan biri olduğu anlaşılmaktadır.

${ }^{3}$ İstanbul'daki pek çok sebil günümüzde büfe olarak kullanılmaktadır. Bkz. URL-1. https://www.sabah.com.tr/pazar/2014/06/15/osmanli-sebilleri-eskiden-hayratti-simdi-bufe (Erişim Tarihi:08.11.2018).

Osmanlı Döneminden beri Kiliseler, müze olarak yeniden işlevlendirilmektedir. Bu örneklerden hareketle Isparta, Doğancı'da bulunan Aya İshotya (Yorgi) Kilisesi'nin günümüzde atıl durumda olmasına işaret edilmekte ve bir müze olarak yeniden işlevlendirilmesi önerilmektedir (Aydın ve Şahin, 2018, s. 66-65).
} 
konumlanmış evlerde yaşayan kişilerle görüşmeler yapılmıştır. Edinilen bilgiler değerlendirilmiştir. Literatür araştırmasında, Mundell'in (1982) “Deux églises de Mésopotamie du Nord: Ambar et Mar Abraham de Kashkar" başlıklı makalesinde ilk kez kiliseden bahsedildiği görülmüştür. Yapının isminin geçtiği diğer az sayıdaki yayınlar Dara Antik kenti ile ilgili araştırmalar olup Ambar Köyü Kilisesi'ne kısaca değinen çalışmalardır (Lillington-Martin, 2007, s.302, 308-309; Lillington-Martin, 2013, s.606-607; Keser- Kayaalp ve Erdoğan, 2017, s. 164-165).

Mardin ve ilçelerindeki pek çok dini ve sivil mimari örnekleri, yörenin kültür mozaiği kimliğini oluşturmaktadır. Son yıllarda yörenin taşınır ve taşınmaz kültür varlıklarını konu alan bazı akademik çalışmaların ${ }^{5}$ yapıldığını görmek memnuniyet vericidir. Ancak, Mardin ve ilçelerinin kültür potansiyeli düşünüldüğünde bu tür araştırmaların daha da artıııması gerektiği görülmektedir. Bilgilendirme ve farkındalık yaratması umulan akademik çalışmaların; bilimsel yöntem ve teknikler ışığında incelediği ve değerlendirdiği kültür mirasının korunmasına yönelik ortaya koyduğu bilgilerin ve bulguların, risk altında bulunan eserlere yapılacak restorasyon ve koruma çalışmalarına kaynaklık etmesi beklenmektedir. Bu bağlamda; Ambar Köyü Kilisesi'nin tanıtıması, hali hazırdaki durumunun belgelenmesi, hasarlı ve risk altında bulunduğunu ortaya koyması ve bu durumdan yapının kurtarılmasına yönelik yeniden işlevlendirilme önerisi sunan çalışma önemli görülmektedir. Çalışmanın, söz konusu kilisenin günümüze kazandırıması için yapılabilecek müdahaleler için veri ve kaynak sunarak katkı sağlayacağı düşünülmektedir.

\section{Ambar Köyü'nün Bulunduğu Yörenin Kısa Tarihçesi}

Mardin Merkeze bağlı Ambar Köyü'nde bulunan kilisenin tarihsel değerinin anlaşılması için yörenin tarihine kısaca değinmek faydalı olacaktır. Mezopotamya'nın önemli kentlerinden biri olan Mardin'in tarihi milattan öncesine dayanmaktadır. Ticaret yollarının üzerinde yer alması ve coğrafi konumu itibariyle birçok kültüre de ev sahipliği yaptığı anlaşılan Mardin, din ve etnik köken bakımından çeşitlilik gösteren bir yapıdadır.

Mardin; Sümerler (MÖ. 2850), Akadlar (MÖ. 2350-2150), Babiller (MÖ. 2100), Hititler (MÖ. 1930), Mitaniler (MÖ. 1468), Asurlular (MÖ. 1367-1364-1190), Medler, Persler Helenler (MÖ. 331), tekrar Persler (MÖ. 250), Aramiler (249), Romalılar (MÖ. 292) (Persler ve Romalılar arasında birkaç kez el değiştirmiş), Araplar, Artukoğulları (1108), Karakoyunlular (1406), Akkoyunlular (1469), Osmanlılar (1516) ve Türkiye Cumhuriyeti (1923-Halen) ile devam eden bir tarihi geçmişe sahiptir (Noyan, 2009, s. 13-29; Akyüz, 1998, s.20; Güler, 1998, 178; Uygur, 2015, s.4). Bu kronoloji içinde özellikle PerslerHelenler (MÖ. 331), Persler ve Romalılar arasında (aralıklı olarak MÖ 92'den MS. 639 yılına kadar) birkaç kez el değiştirmiş olduğu bilinen bu bölgede yaşayan halk için çetin şartların yaşandığı kolaylıkla anlaşılabilir. Nitekim güncel kaynaklarda da Persler ve Romalılar arasındaki bölgeyi ele geçirme mücadelesi sonucu özellikle Hıristiyanlar için yıkımların yaşandığı, bu nedenle dayanıklı savunma yapılarının inşa edildiği belirtilmektedir (Palmer, 1990, s.4-5, 149-153). Özellikle bu mücadele ortamının en somut tanığı Dara Antik Kenti'dir. Kent; savunma amaçlı surlar, kapılar ve burçlarla donatılarak garnizon kent olarak kullanılmıştır (Can ve Erdoğan, 2014, 347-371). Dara'nın sınır garnizon kenti olmasında, Nusaybin'in (Nisibis) Persler tarafından ele

\footnotetext{
${ }^{5}$ Mardin'in kültürel mirasının tanıtılması, bunların korunarak turizme kazandırılması gerekliliğini açıklayan, Mardin'de kültür turizminin gelişimine yönelik öneriler sunan ve kültür turizmi açısından ilin zenginliklerini değerlendiren (Günal, 2005, 93-124); Mardin İli'nin Midyat İlçesi'ndeki kültürel çeşitliliği ele alan ve bu kültürel değerlerin turizm potansiyelini irdeleyen (Özgen ve Oçal, 2012, s. 629-643); çok kültürlülüğün mirasının geleceğe taşımasında Mardin örneğini ele alan (Işık ve Güneş, 2015, s. 449-461) akademik çalışmalar bunlardan bazılarıdır.
} 
geçirilmesinin etkisi olmuştur. Daha önce Persler ile Romalıların sık sık karşılaştığı sınır kent olan Nusaybin'e alternatif bir garnizon kent inşa etme intiyacı için, yakın konumdaki Dara kenti inşa edilmiştir (Ahunbay, 1991, s. 391;Kütük, 2018, 119-136). Aslında bu kent sıfırdan inşa edilmemiştir. Nusaybin'e $25 \mathrm{~km}$ yakın, Pers kralı Darius döneminden kalan ve Darius'un ismiyle anılan küçük bir yerleşim yeri olan antik kent; Anastasius (491-518) tarafından 507'de kurulmuş ve Roma İmparatoru Anastasius'a ithafen "Anastasiopolis" olarak adlandırılmıştır (Ahunbay, 1991, s. 391; LillingtonMartin, 2007, s. 299; Kütük, 2018, s.124). Sonrasında da devam eden Pers saldırılarına karşı Jüstinianus (527-565) zamanında kent güçlendirilmiş, tahkim edilmiştir ${ }^{6}$.

\section{Ambar Köyü'nün Yeri-Konumu ve Nüfusu}

Ambar Köyü, Mardin Merkeze bağlı Dara Antik kenti'nin (Oğuz Köyü) 3 km güneyindedir. Köyün ismi, ambar olarak kullanılan bu kiliseden gelmektedir. Bunun dışında köyün adının menşei ile ilgili bir bilgiye ulaşılamamıştır. Köydeki ilk yerleşimin kilise ile başladığı daha sonra genişleyerek bugünkü nüfusuna ulaştığı bilinmektedir. Köy, etrafını görebilecek yüksek bir tepenin üzerine kurulmuş olup, bulunduğu noktadan Dara Antik Kenti'ne bakmaktadır (Fot. 1).

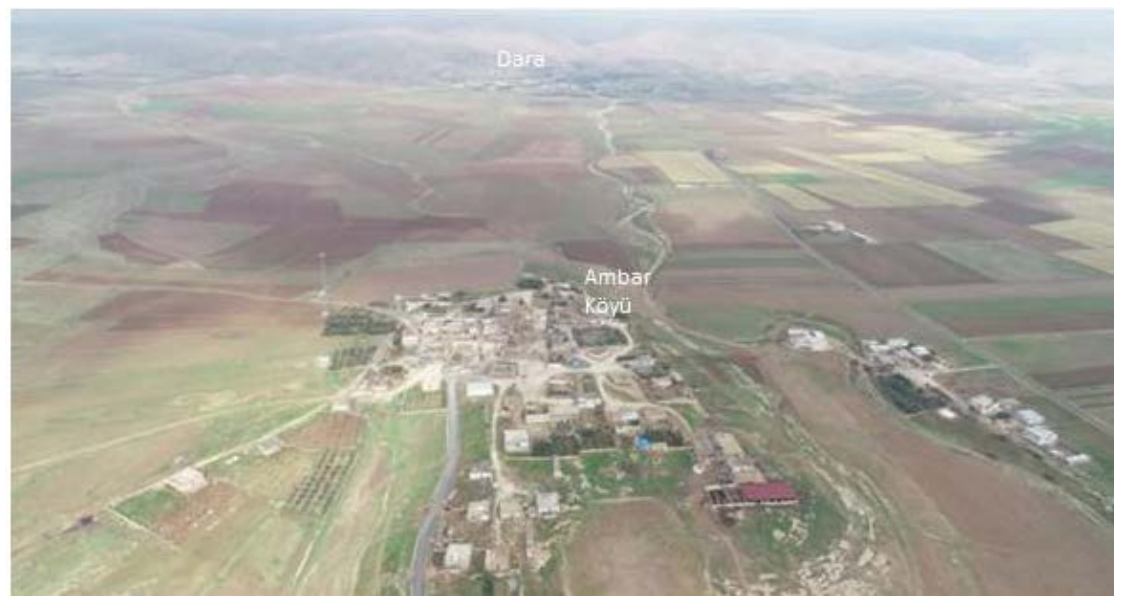

Fot. 1. Ambar Köyünden Dara'ya üstten bakış (Fot. Mardin Müzesi Arşivinden)

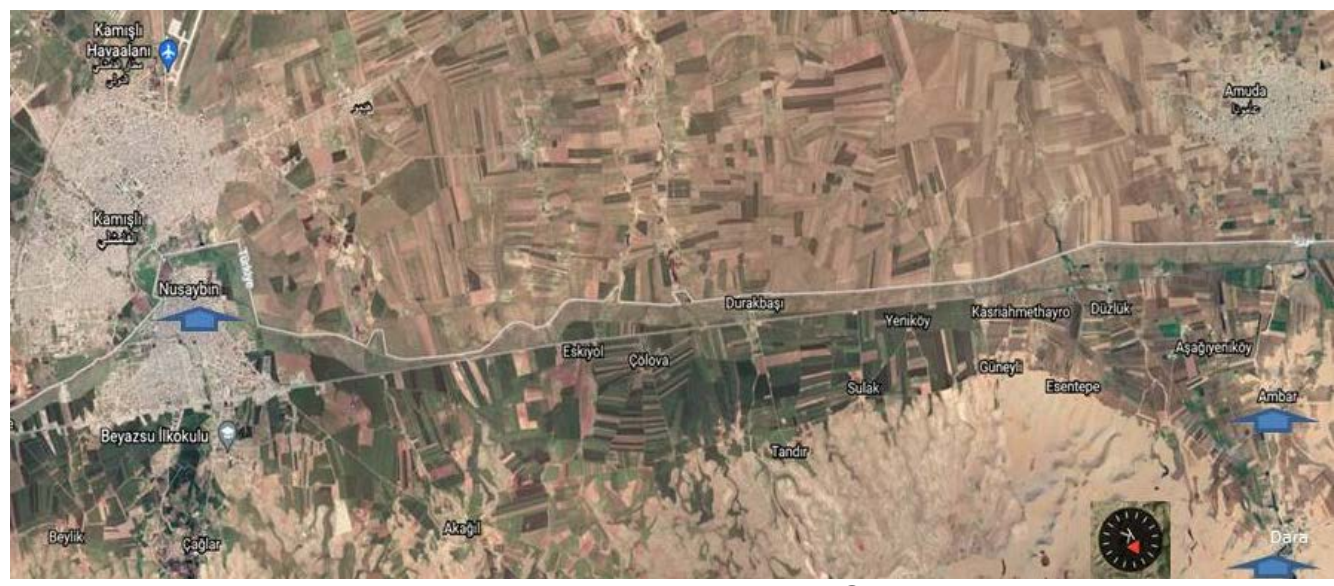

Fot. 2. Dara-Ambar Köyü- Nusaybin Konumu Google Earth görüntüsü

\footnotetext{
${ }^{6}$ 6. yüzyılın önemli tarih yazıcısı Prokopius (d.500-ö.565), Zachariah (d. 465-ö.?), Efesli İoannes (John of Ephesus d. 507- ö.588) ve Evagrius (6.yy) gibi geç Antikçağ kaynakların anlatımına başvurarak, Roma İmparatoru Anastasius'un (491-518) ve I. Jüstinianus'un (527-565) Dara kentini tahkim edilmesinin nedeni, önemi ve bu sürecin tarihsel gelişiminin detaylı açıklaması için bkz. Kütük, 2018, s.119- 160. Ayıca bu kaynakta bkz. Dipnot: 32, 37, 46.
} 


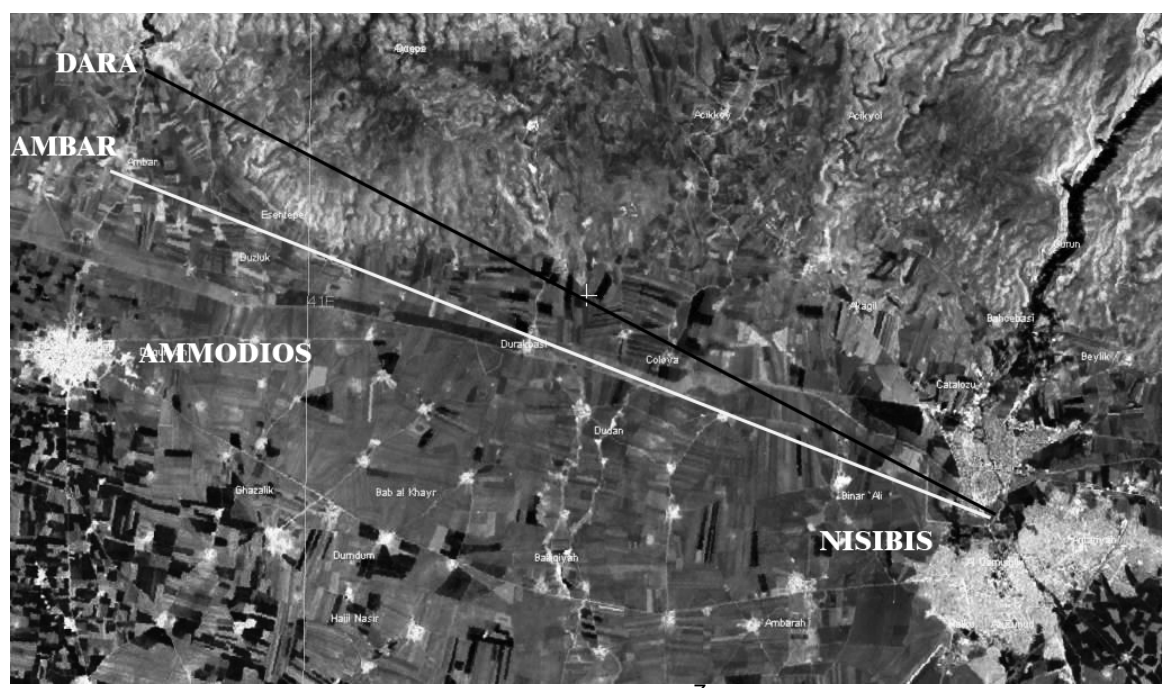

Fot. 3. Bölgenin NASA World Wind ekran görüntüsü'. Beyaz çizgi, Ambar'dan Nusaybin'in gözetlendiğini; Siyah çizgi, Nusaybin'den Dara'nın görünmediğini göstermektedir (LillingtonMartin, 2007, s. 301'den alınmıştır.)

Köyün, Nusaybin ve Dara arasındaki konumu topografik açıdan dikkat çekicidir (Fot. 2). Pers-Roma savaşlarında Dara'yı elinde tutan Romalılara siper olabilecek ve böylece üstünlük kazandırabilecek bir konumdadır. Nitekim 530 Pers-Roma savaşlarını topografik açıdan değerlendiren Lillington-Martin; dönemin görgü tanığı olarak kabul edilen Prokopius'un (d.500-ö.565), Zachariah'ın (d.465-ö.?) ve Malalas'ın (d. 491ö.578) anlatımına da dayanarak, siper tasarımı ve taktiği ile kullanılan Ambar Tepesinin Romalılara üstünlük kazandırdığını aktarmaktadır (Lillington-Martin, 2007, s.302, 308309; Lillington-Martin, 2013, s.606-607). Bu bağlamda Nusaybin (Nisibis) ve Dara arasında kalan Ambar Köyü'nün stratejik konumunun önemi görülmektedir (Fot. 3.).

Günümüzde Ambar Köyü'nde 50 hane bulunmaktadır. Köyün kamu binaları; bir ilkokul, bir mescit ve bir taziye evinden ibarettir. Köyün geçim kaynağı tarım ve hayvancılıktır. Ancak bu da sınırlı ve yetersizdir. Bu nedenle gençlerin başka şehirlere göç ettiği ifade edilmektedir ${ }^{8}$.

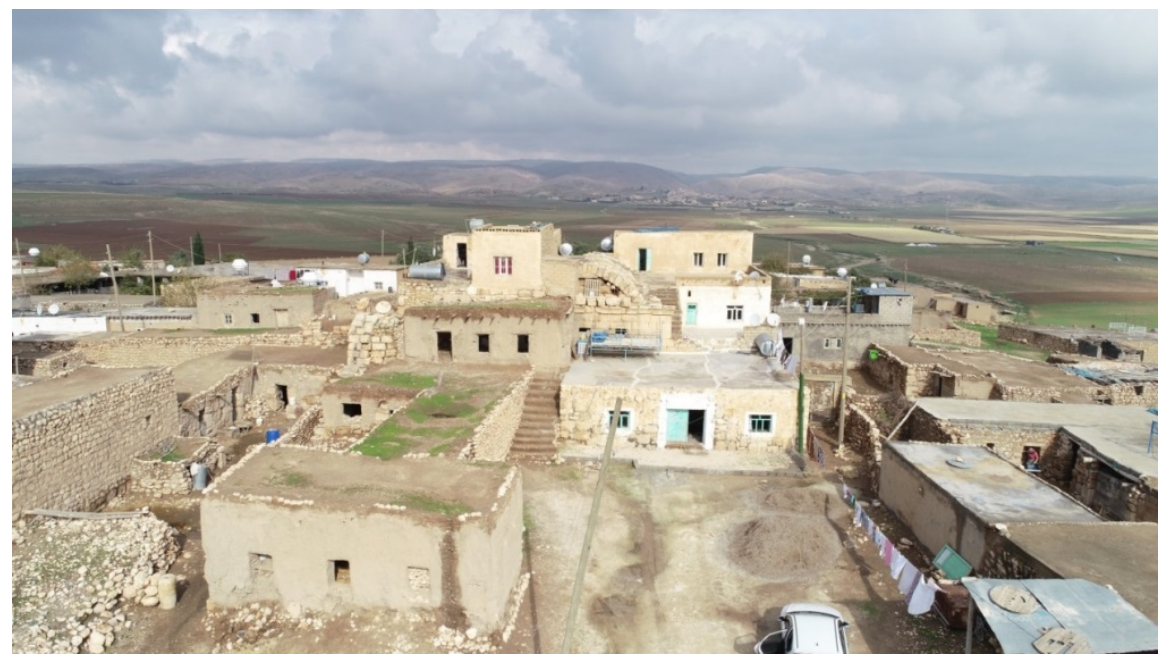

Fot. 4. Kiliseyle iç içe geçmiş köy evleri (Fot. Mardin Müzesi Arşivinden).

\footnotetext{
${ }^{7}$ Bu görüntü, Ambar Tepesi'nin Dara ve Nusaybin arasında stratejik bir konumda olduğunu göstermesi bakımından önemlidir.

${ }^{8}$ 8.11.2018 tarihinde köy sakinleri ve muhtar ile yapılan görüşmeden bilgiler edinilmiştir.
} 
Köyü oluşturan konutlar, kendine özgü yerel özellik taşıyan kâgir yapılardır. Bu evlerin ortasında anıtsal nitelikte bir kilise yer almaktadır. Kilise, çevresindeki bu evlerle iç içe geçmiş durumdadır (Fot. 4). Kilisenin bitişiğine ve üzerine kurulmuş, üçü yanda ikisi üstte olmak üzere, beş kâgir ev vardır. Geleneksel dokuya sahip köy konut tipindeki bu evler, eklenti olup kilisesin dokusundan farklılık göstermektedir. Evler 1973'te alınan tapularla özel mülkiyet statüsündedir. Tescilli ${ }^{9}$ bir taşınmaz kültür varlığı olan kilise; tapuda 237 'de kayıtlı olup, hazine malıdır.

Konutların ve bahçelerinin duvarlarında kısmen devşirme blok taş malzemeler kullanılmıştır. Özellikle kiliseye yakın konumlanmış evlerin ve bahçelerin duvarlarında bunu görmek mümkündür. Devşirme malzemenin, kiliseye bağlı ancak günümüzde mevcut olmayan diğer birimlerden elde edildiği düşünülmektedir. Nitekim kilisenin etrafında temel seviyesinde kalmış yapı kalıntı izleri gözle görülür durumdadır.

\section{Ambar Köyü Kilisesi}

\subsection{Kilisenin Tarihçesi}

Kilise, günümüzde "Ambar Köyü Kilisesi" olarak anılmaktadır. Ancak bu yapının gerçek ismi olmamalıdır. Yapılan araştırmalar sonucu kilisenin ismini verebilecek tek bir bilgiye ulaşıımıştır. Söz konusu kaynak Süryani Azizlerin yaşam öykülerini anlatan bir kitabın 1464 tarihli çevirisidir. Süryanice yazılmış Mor Abay'ın yaşam öyküsünü aktaran bu kaynağın verdiği bilgiye göre; Mor Abay, annesi Estina'ya (Estina: Beyaz, demektir) rüyasında görünüp bulunduğu yerde kendi adına bir manastır inşa etmesini istedi. Annesi de rüyasında gördüğü gibi Dara Şehrinin aşağısında bir tepenin üzerinde bir manastır inşa ettirir ve "Beyaz Manastır" adını verir. Bu manastır Mor Yuhanon'un gözetmenliğinde yapılır. .... Mor Yuhanon, Beyaz Manastırı inşa ettirir ve ilk reisi oldu. Bundan dolayı da bu manastır, Mor Yuhanon'un Beyaz Manastırı adıyla anıldı. ${ }^{10 "} \mathrm{Bu}$ kaynakta geçen konum bilgilerinin Ambar Köyü'nün bulunduğu tepeyi işaret ettiği anlaşılmaktadır. Ancak bunu destekleyecek başka bir kaynak yoktur.

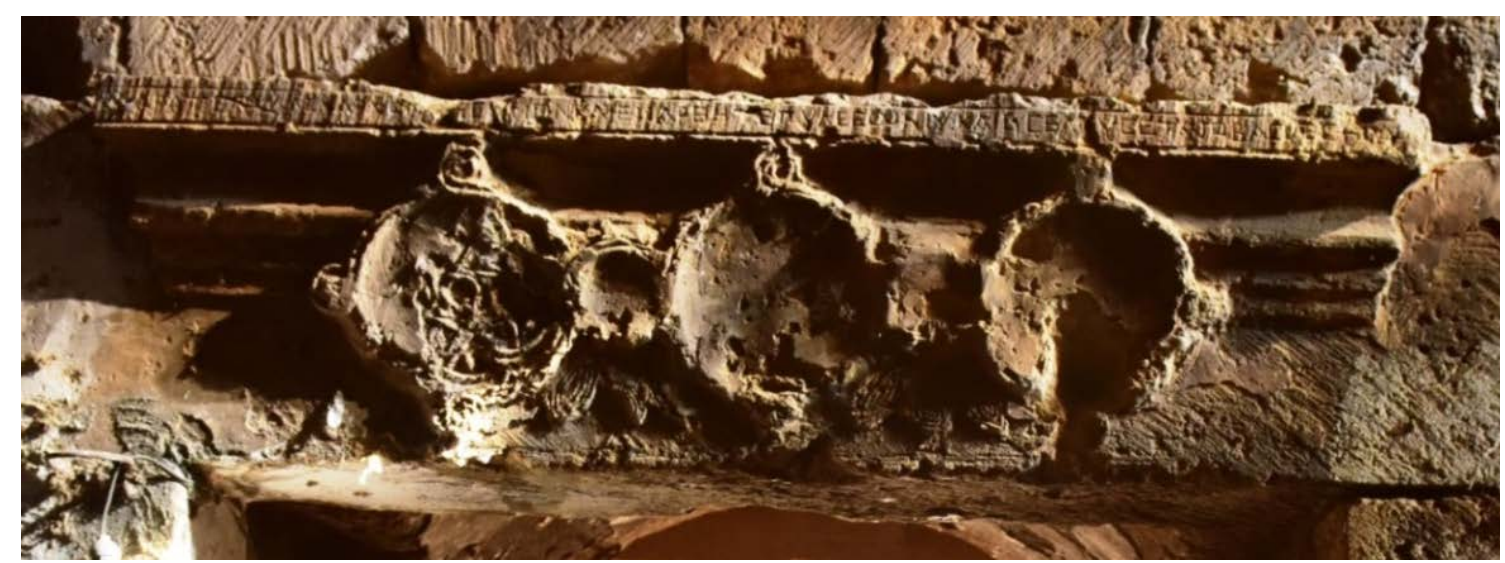

Fot. 5. Lento üzerindeki tek satırlı Yunanca yazı ve üçlü rozet bezeme (Fot. Tehsin Baravi).

Yapının kimin tarafından ve ne zaman yapıldığına dair bir kitabesi yoktur. Bununla ilgili kaynaklarda da bir bilgiye rastlanmamıştır. Araştırmacılar, Ambar Köyü Kilisesinin askeri bir işlevi olabileceğini veya 530 zaferinin anması için yapıldığına dair ihtimalleri zikretmektedir (Lillington-Martin, 2007, s. 308-310; Keser- Kayaalp ve Erdoğan, 2017,

\footnotetext{
${ }^{9}$ Ambar Köyü Kilisesi, Diyarbakır Kültür ve Tabiat Varlıklarını Koruma Bölge Kurulunun 25.01.2007 gün ve 281 sayılı kararı ile tescillenmiştir.

10 17.12.2018 tarihli görüşmede H. Gabriel AKYÜZ'ün yaptığı çeviriden alınmıştır. Bu çeviriyi ve kaynağı bizimle paylaştığı için kendisine çok teşekkür ederiz.
} 
s.165). Nitekim yapıdaki bazı detaylar da bu dönemi destekler niteliktedir. Örneğin naostan apsise geçiş sağlayan açıklığın üzerinde bulunan lentoda üçlü rozet şeklinde bir bezeme ve tek satır halinde Yunanca büyük harflerle yazılmış bir metin dikkat çekicidir. Bu yazı ve bezeme 6 yüzyıl Erken Dönem Bizans sanatı özelliği taşımaktadır (Fot. 5). Bununla birlikte, yapının plan tipi ile dış cephe düzenlemesinin benzerlik gösterdiği anlaşılan 6. yüzyıl tarihli Midyat'taki Mor Gabriel Kilisesi ${ }^{11}$ (Plan 2) ile Salah'taki Mor Yakup Kilisesi'nin ${ }^{12}$ (Plan 3) varlığı da Ambar Köyü kilisenin 6. yüzyıl tarihli olabileceğini düşündürmektedir. Nitekim bu üç kilisenin planları incelendiğinde aynı plan şemasının tekrarlandığı anlaşıımaktadır.

\subsection{Kilisenin Mimari Özellikleri}

Kilise, günümüzde sağlam olup ambar işleviyle kullanılmaktadır. Çevresine ve üzerine yapılmış konutların arasında saklı bulunan yapı dıştan anlaşılır durumda değildir. Bu nedenle yapının tanınmasını sağlayacak yeterlilikte mimari analiz yapılamamaktadır. Ancak dıştan görünür durumdaki bazı yapı elemanlarında ve iç kısımda gözlem yapılabilmektedir. Özellikle içi kısımda, yapının anıtsallığı ve büyüklüğü izlenebilmektedir.

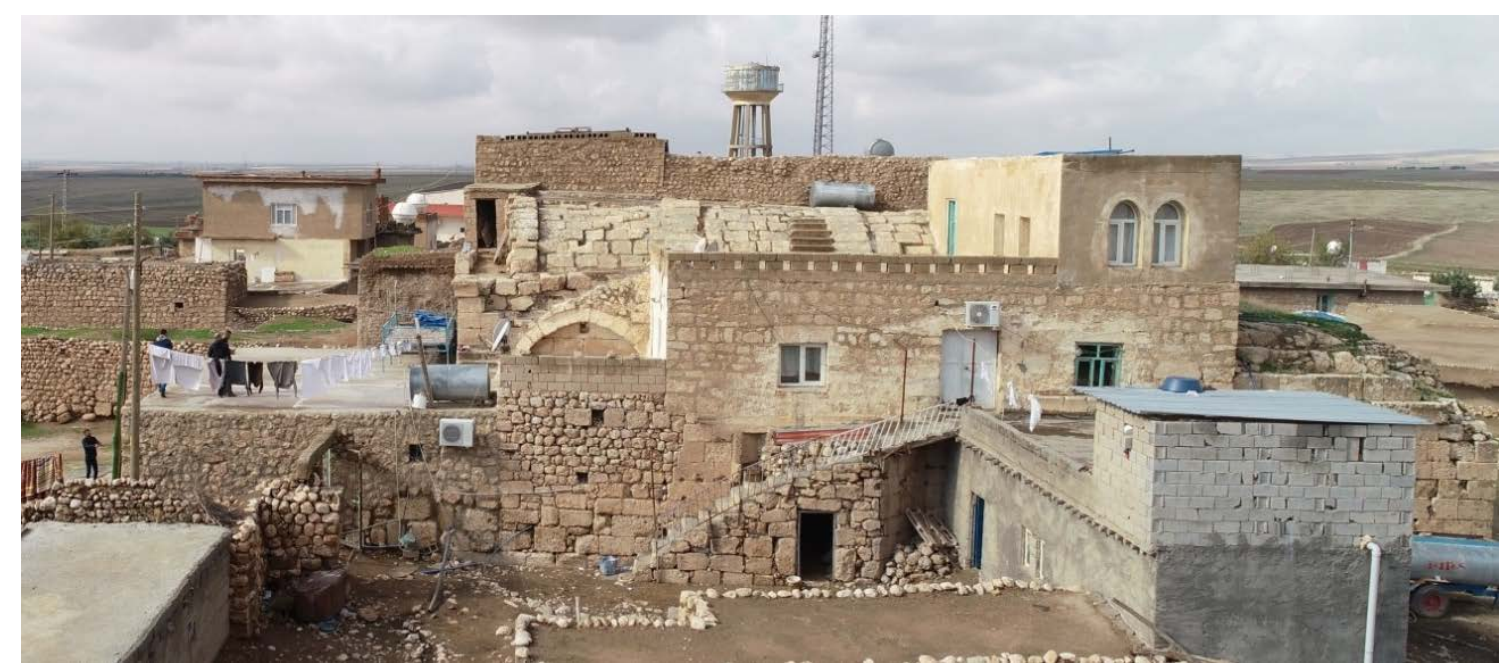

Fot. 6. Kilisenin doğu cephesi (Fot. Mardin Müzesi Arşivi).

Yapıya, doğu cephede sonradan yapılmış açıklıkla apsisten giriş sağlanmaktadır (Fot. 6). Burada biri üstte diğeri bitişik yapılmış iki konut adeta yapıyı gizlemiştir. Yine de kilisenin bu cephede; dışarı taşkın apsisinin iki cephesi, üstte yarım daire bir kemer ve tonoz örtü sistemi görülebilmektedir.

\footnotetext{
${ }^{11}$ Mor Gabriel Manastıındaki Büyük Kilise olarak bilinen yapı, Doğu Roma İmparatoru Anastasius döneminde 512'de inşa edildiği yazılmaktadır (Bilge, 2011, s. 100-105).

${ }^{12}$ Salah'taki Mor Yakup Kilisesi de Midyat'taki Mor Mor Gabriel Kilisesi ile benzer plan sahip olması nedeniyle 6. yüzyıla tarihlendirilmektedir (Hollerweger, 1999, s.126-127; Bell, Berchem, ve Strzygowski, 2015, s. 179, resim159).
} 


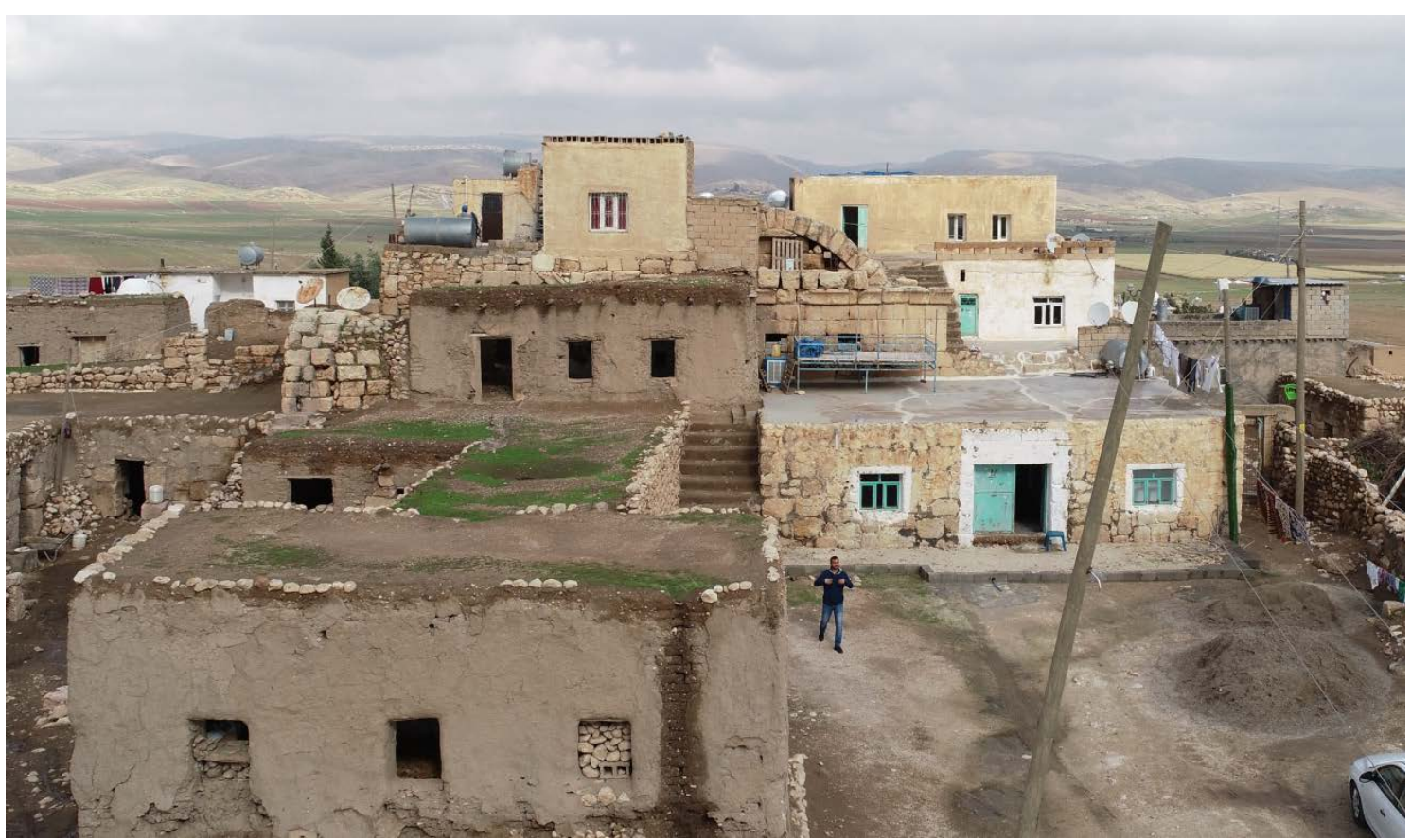

Fot. 7. Kilisenin güney cephesi (Fot. Mardin Müzesi Arşivi).

Güney cephede üstte ve önde yapılmış eklentilerle kilise görünmez hale gelmiştir (Fot. 7). Yine de bir kısım duvar örgüsü ve tonozun kemer kısmı izlenebilmektedir.

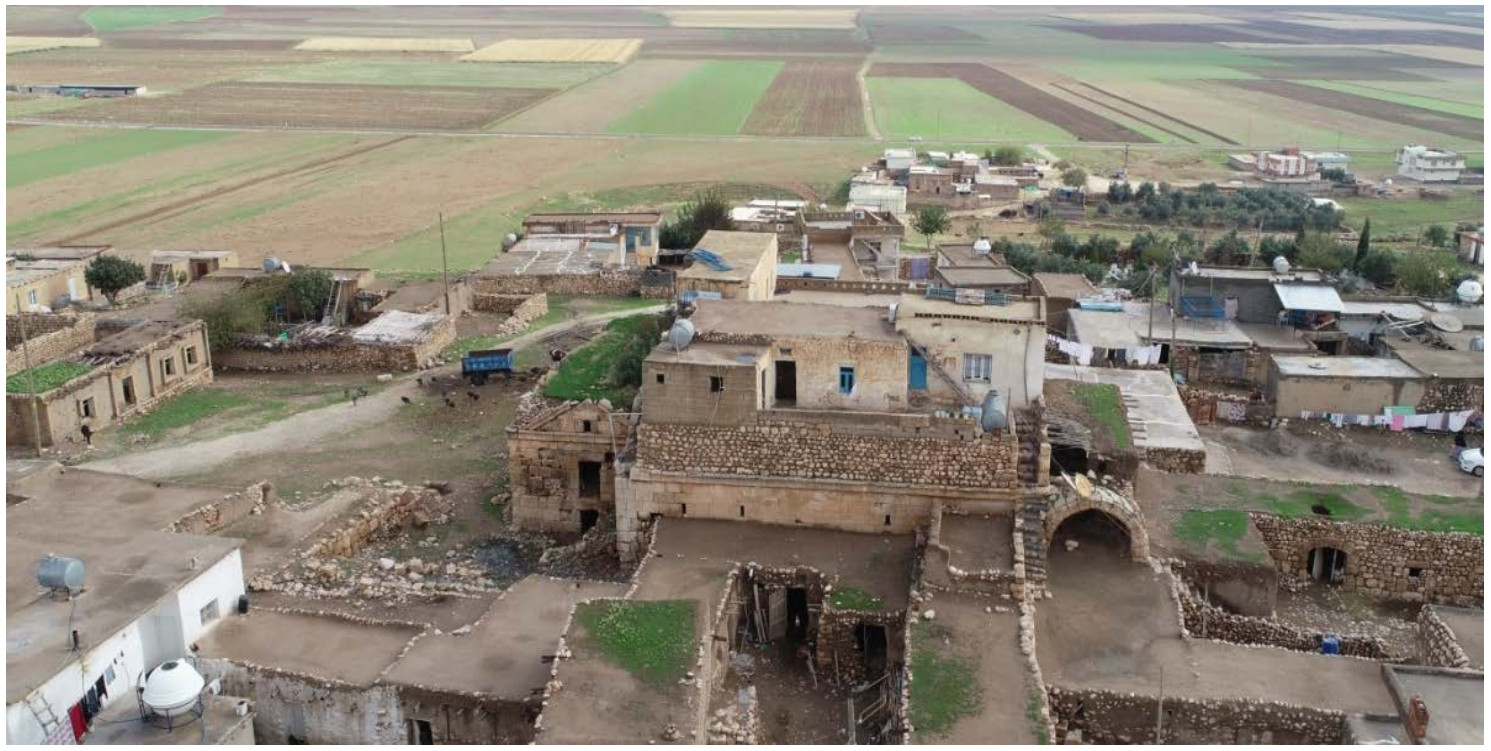

Fot. 8. Kilisenin batı cephesi (Fot. Mardin Müzesi Arşivi). 


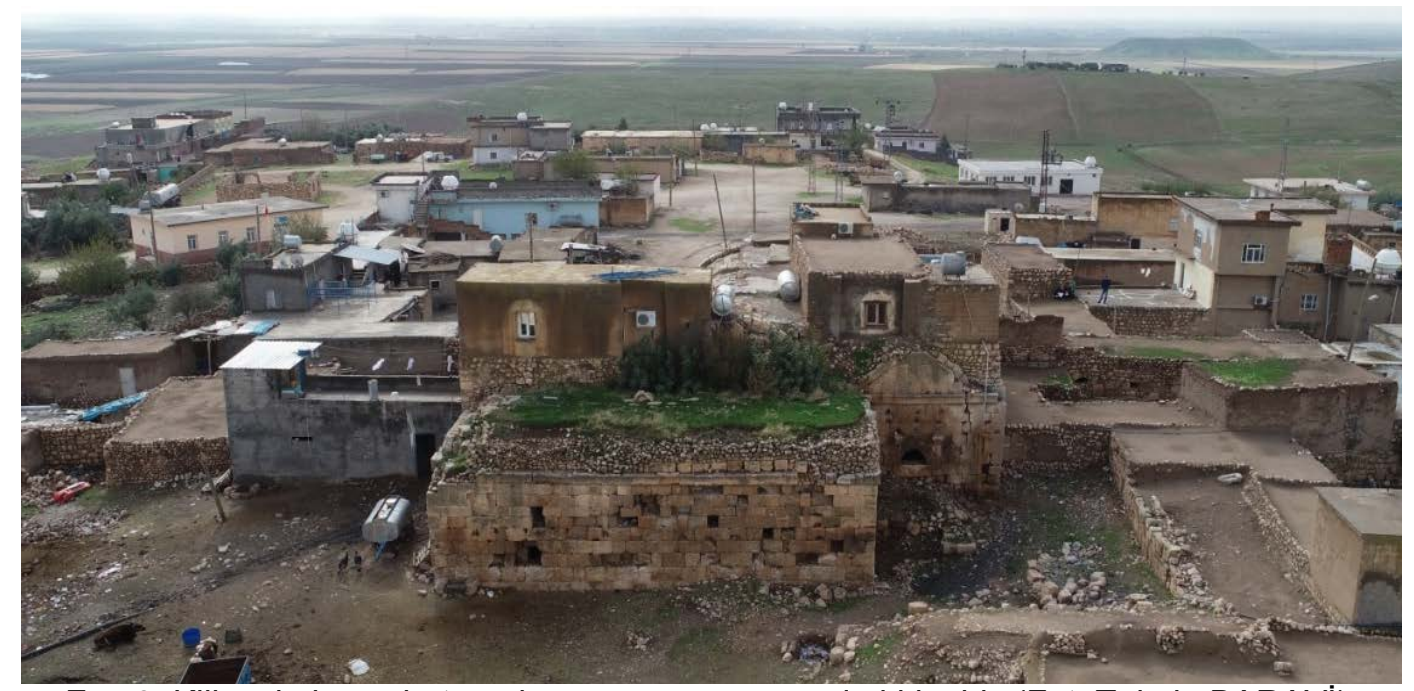

Fot. 9. Kilisenin kuzeybatısından görünüş, üçgen alınlıklı giriş (Fot. Tehsin BARAVI).

Batı cephesinde; yapının üzerine kurulmuş bir ev ve yapıya bitişik yapılmış ahır bulunmaktadır (Fot. 8). Yukarıdaki evin altındaki moloz taş duvar örgüsü ile aşağıda eklenti bir ahırın arkasında kilisenin düz kesme taş duvar örgüsü ve sağda şapele ait taş işçilikli yarım daire formunda kemer görülebilmektedir.

Dara Antik Kenti'ne bakan kuzey cephe, kilisenin önü açık tek cephesidir (Fot. 9). Yapının kuzey cephesinde doğu-batı uzantılı iki birim sıralanmaktadır. Soldaki daha küçük ve doğudan bir giriş açıklığına sahiptir. Sağdaki daha uzun ve iki katlı olup batıdan bir giriş açıkığı bulunmaktadır. İçten ve dıştan beşik tonoz örtülü olan bu bölümler ayakta ancak harap olmuş vaziyettedir. Düzgün kesme taş tekniğinde örülmüş kuzey cephe duvarında yer yer sökülmüş taşların boşlukları görülebilmektedir. Bu birimin üçgen alınlık ile vurgulanan girişi, intişamlı görünmektedir (Fot. 10). Bununla birlikte kilisenin kuzeyinden girişi sağlayan üzeri yarım daire kemer ile sonlanan atkı kemerli bir açıklık da yine bu cephededir. Açıklığın üzerindeki üçgen alınlık, kilisenin anıtsalığını yansıtmaktadır. Buradaki üçgen alınlıklar ve bingi izleri bu kısmın, yapının ana giriş açıklığı olabileceğini düşündürmektedir.

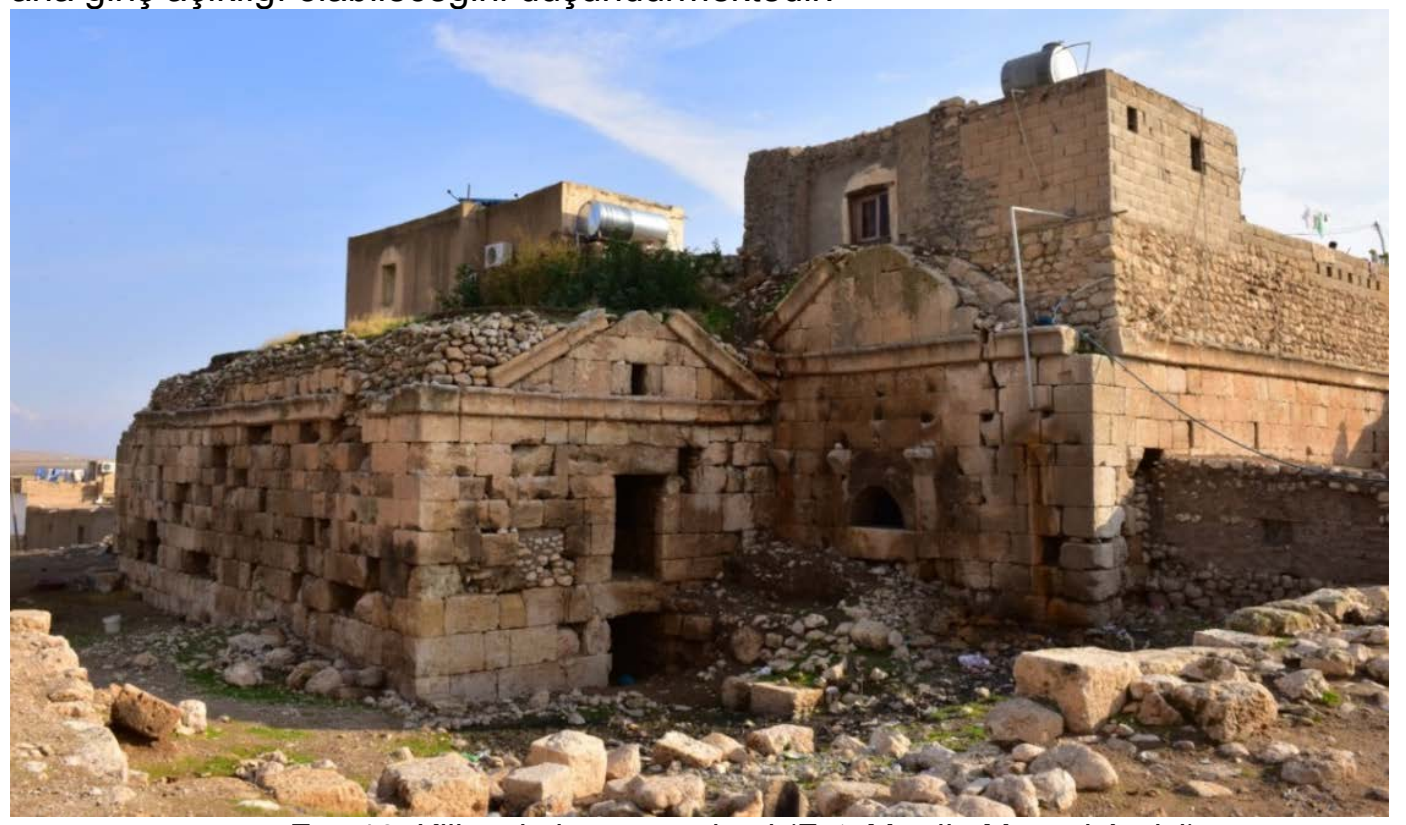

Fot. 10. Kilisenin kuzey cephesi (Fot. Mardin Müzesi Arşivi). 
Kilisenin çevresinde temel seviyesindeki mimari kalıntılardan hareketle, bu yapının dışında başka birimlerin de olduğu hatta buranın bir yapı kompleksi olabileceği düşünülmektedir. Bu alanda yapılacak kazı ve temizleme çalışmaları sonucunda daha sağlıklı bilgilere ulaşılabilir

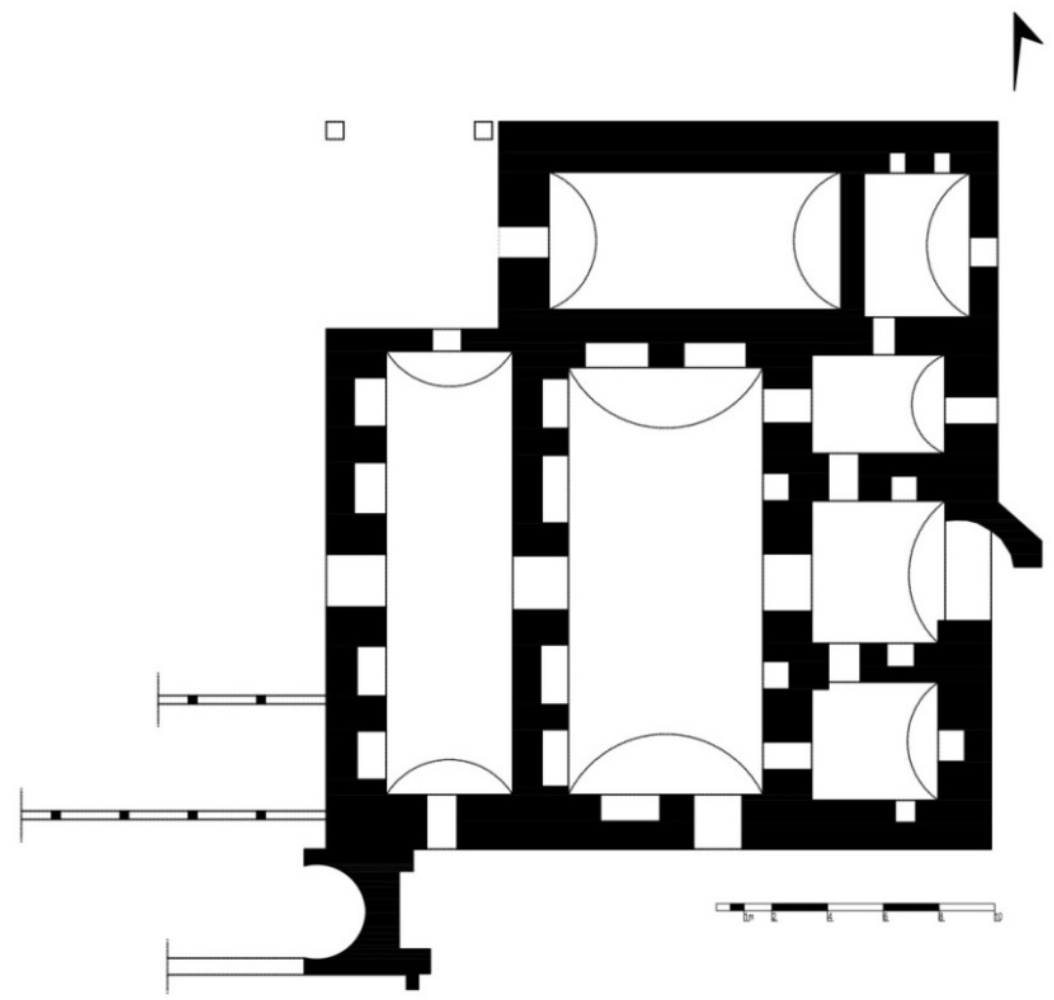

Plan 1. Ambar Köyü Kilise Planı (Mundel Mango, 1982'den alınarak yeniden çizilmiştir).

Kilise $^{13}$, kuzey-güney uzantılı dikdörtgen bir alana sahip olup apsise göre, enine bir plan gelişimi göstermektedir (Plan 1). Yapı, biri güneyden biri batıdaki narteksten olmak üzere iki giriş açıklığına sahiptir. Büyük bir beşik tonoz ile örtülü tek mekânlı naosta (ana mekân); doğuda iki, kuzeyde iki, batıda dört ve güneyde bir olmak üzere dokuz büyük yuvarlak kemerli nişler vardır. Güneydeki nişlerden biri, naosa giriş sağlayan kapı açıklığıdır. Ancak yığın yapılmış saman torbaları nedeniyle kapatılmıştır. Bu cephenin üst kısmındaki üçlü pencere açıklığıyla ana mekân aydınlanmaktadır. Diğer cephelerde pencere açıkığı bulunmamaktadır (Fot. 11 ve 12). Yapının içi oldukça loş ve mistiktir. Doğu cephede bulunan apsise ve iki yanda birer tane bulunan pastoforium (gnizo) hücrelerine açılan üç taş işçilikli lentolu açıklık mevcuttur (Fot. 13). Yanlardaki açıklıklardan daha büyük tutulmuş ve üzerinde üçlü rozet ile Yunanca metin bulunan ortadaki lento açıklık ile kutsal alan bemaya geçilmektedir (Fot. 14). Doğu batı uzantılı ve iki yan hücreye giriş açıklığı bulunan bema, içten yarım daire dıştan üç cepheli apsis ile sonlanmaktadır (Fot. 15). Günümüzde apsis tahrip edilerek oluşturulmuş açıklık ile yapıya giriş sağlanmaktadır. Naos, bema ve yan hücreler düzgün kesme taş duvar tekniğinde örülmüş beşik tonoz örtülür. Yapının zemin kısmı orijinal değildir. Uzun yıllardır hayvan barınağı ve ambar olarak kullanılması nedeniyle yapının zemini oldukça yükselmiş görünmektedir. Hali hazırdaki durumu dikkate alınarak yapılan ölçümlere göre; apsis yüksekliği 3.75, ana mekân (naos) yüksekliği 8.37 ve narteks yüksekliği 6.78 metredir. Yapının alanı $580 \mathrm{~m}^{2}$ 'dir.

\footnotetext{
${ }^{13}$ Yapıyı, Dara Antik kent ile ilişkilendiren araştırmacılar kentin çevresindeki yapılarla noktalandığını belirtmektedir (Keser- Kayaalp ve Erdoğan, 2017, s. 153-175).
} 


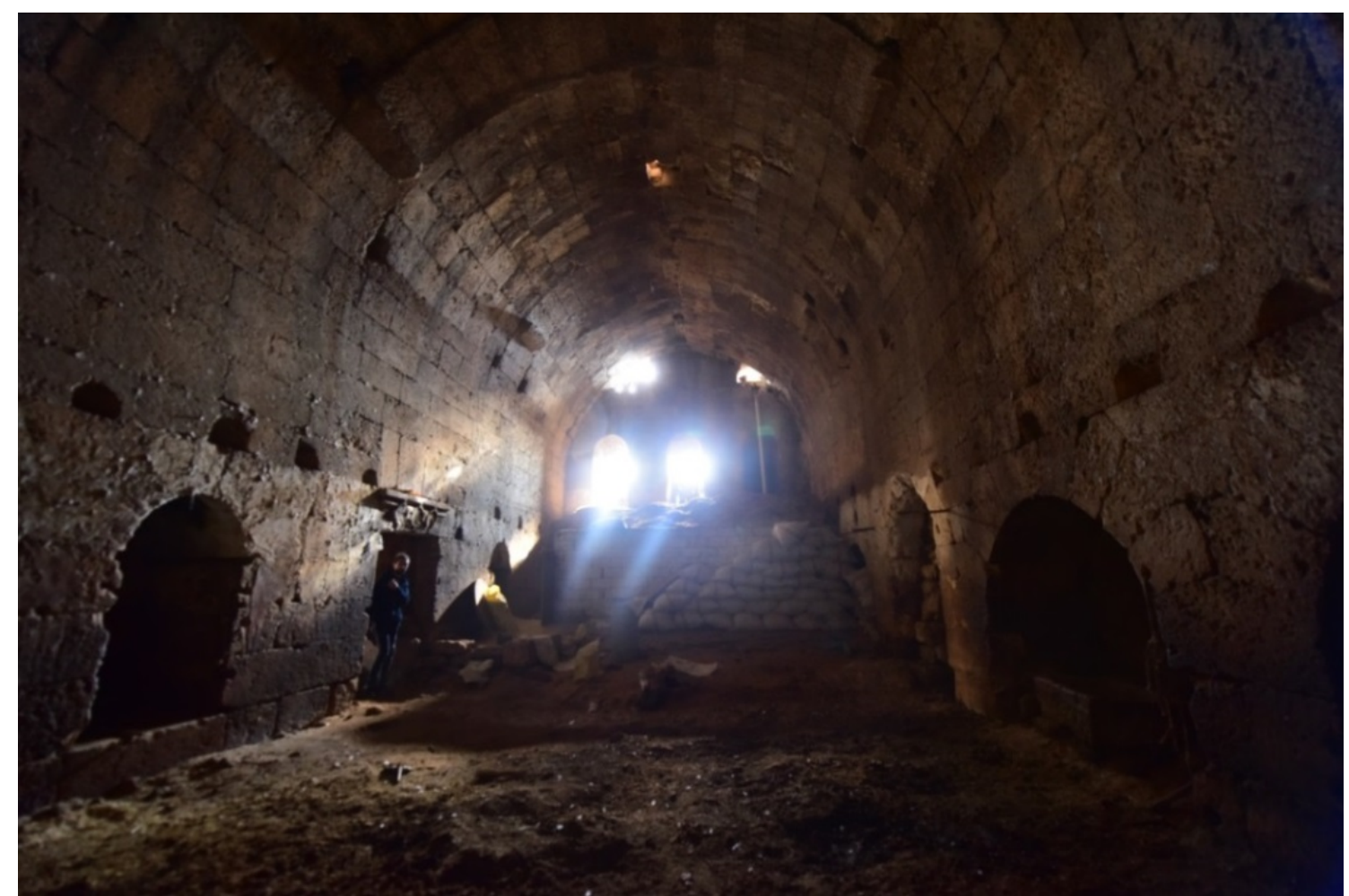

Fot. 11. Naosun güney cephesine bakış (Fot. Tehsin BARAVi).

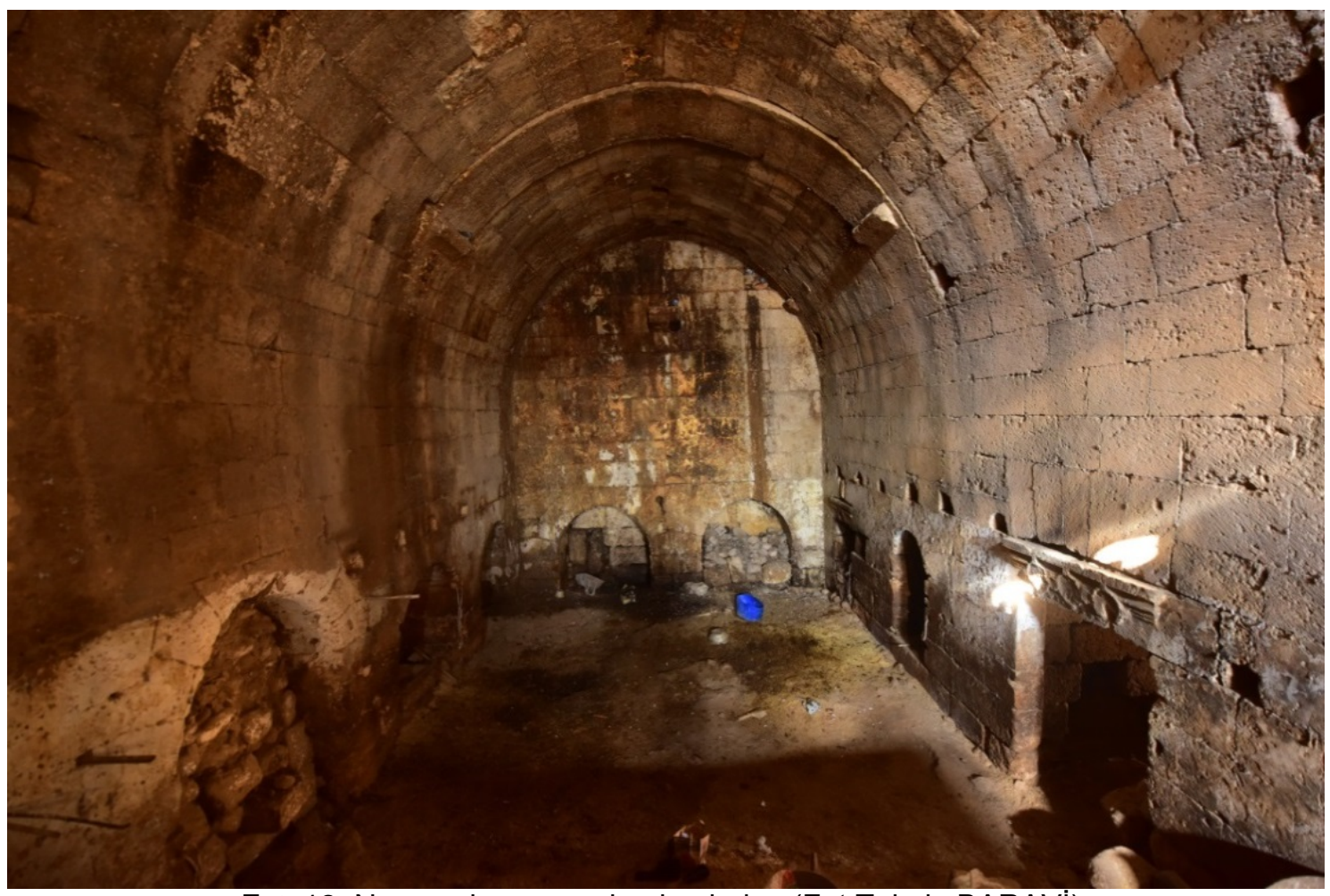

Fot. 12. Naosun kuzey cephesine bakış (Fot.Tehsin BARAVi). 


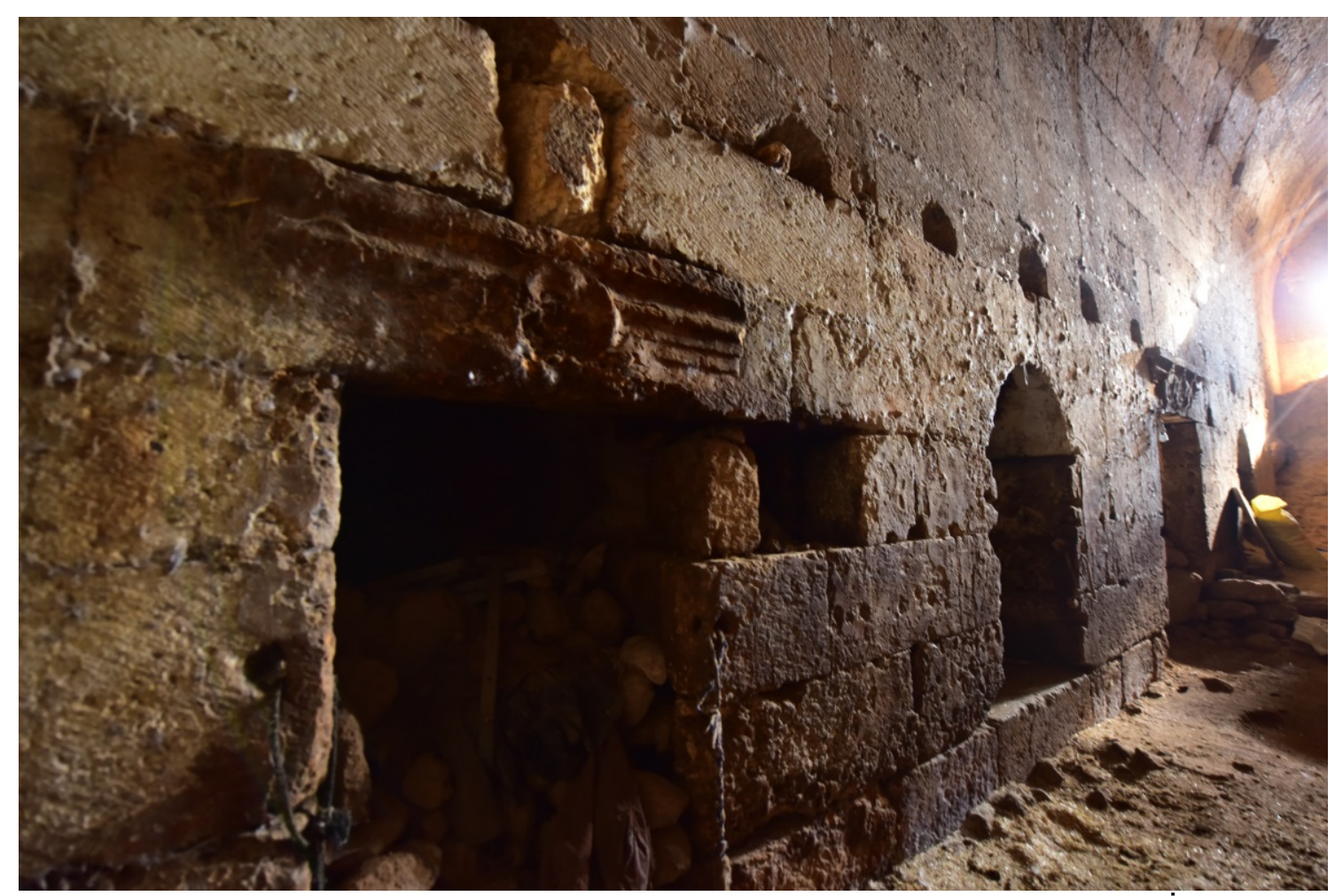

Fot. 13. Doğu cephesindeki lento açıklıklı girişlere bakış(Fot.Tehsin BARAVi) .

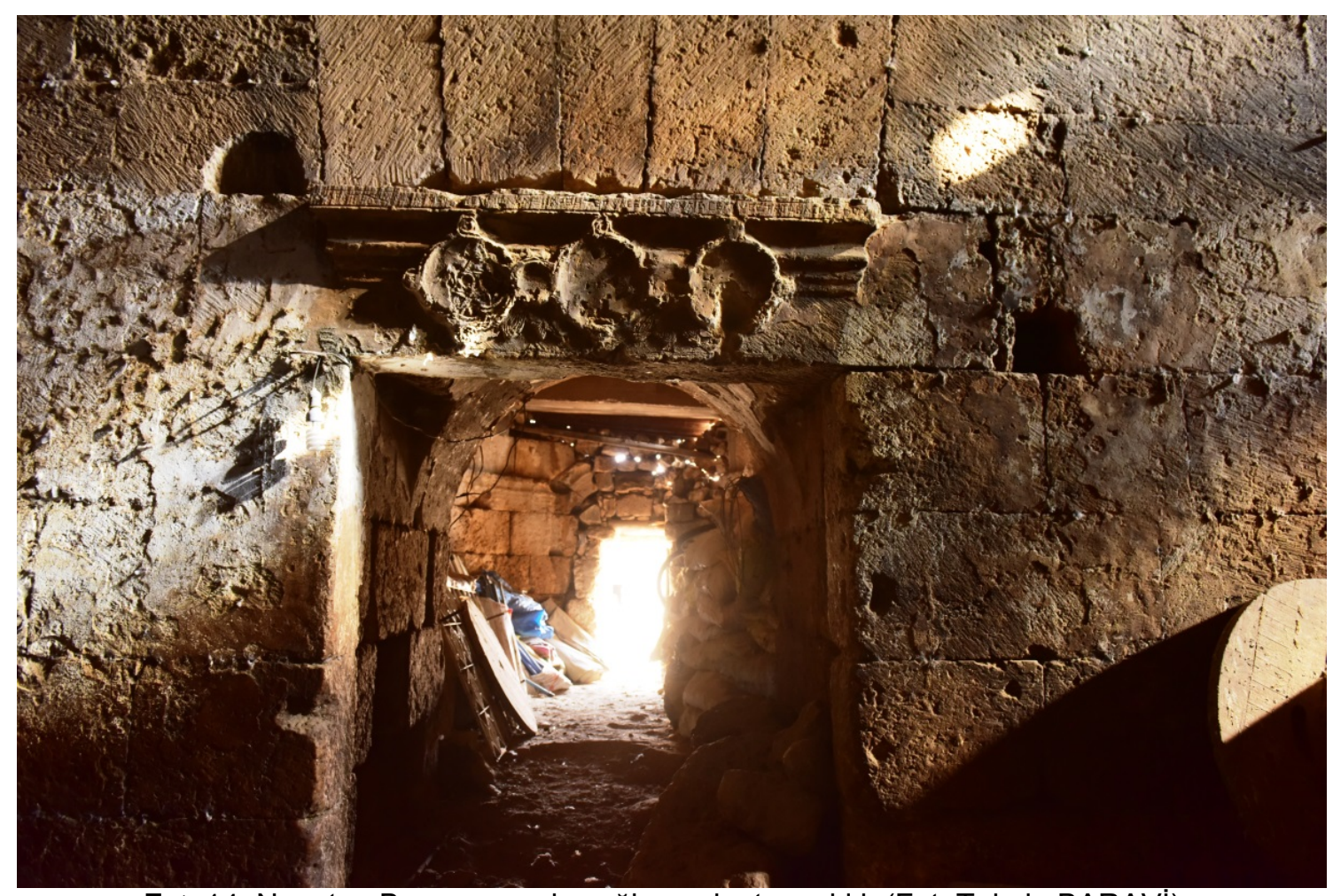

Fot. 14. Naostan Bemaya geçiş sağlayan lento açıklık (Fot. Tehsin BARAVi) . 


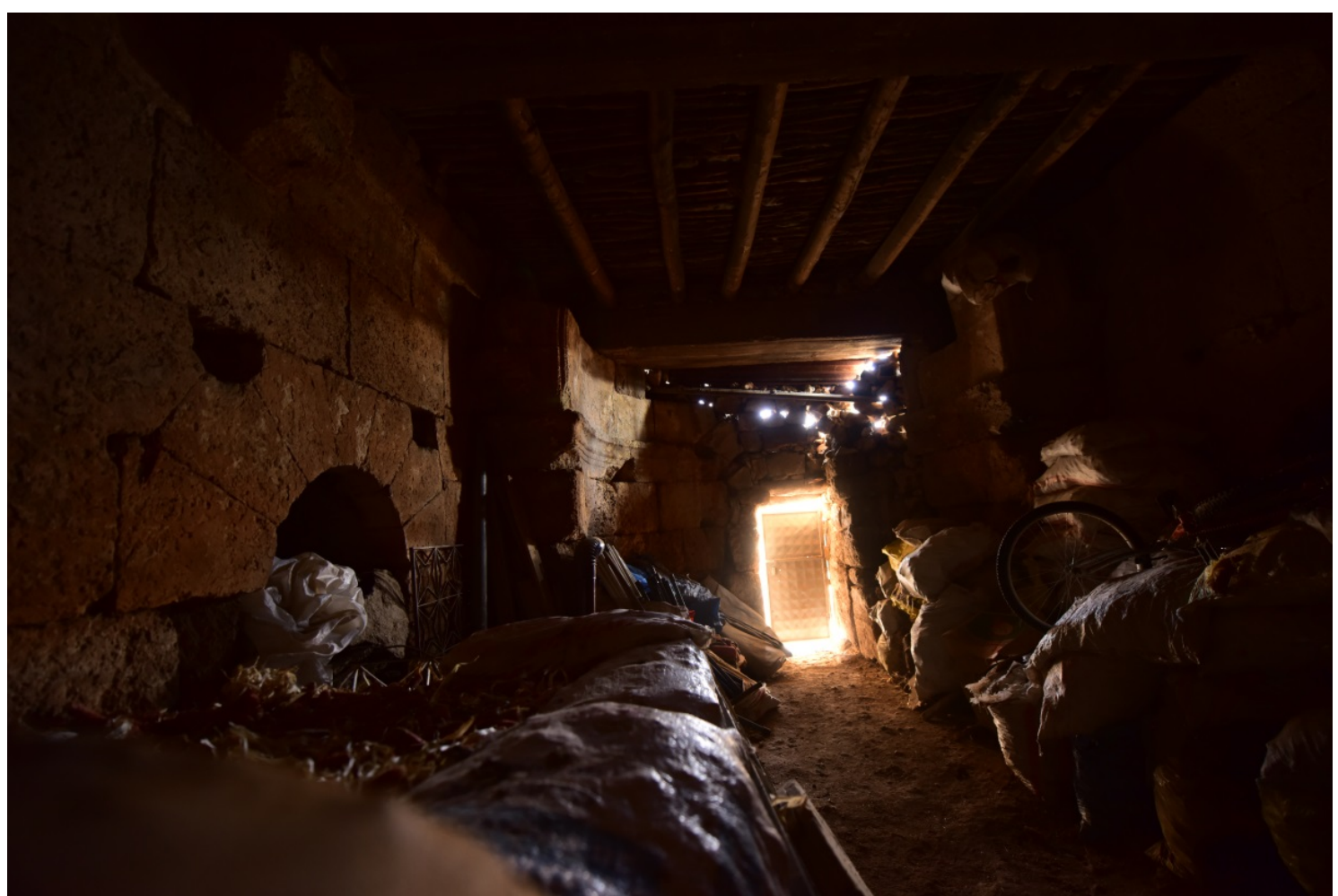

Fot.15. Bemadan apsise bakış (Fot. Tehsin BARAVi).

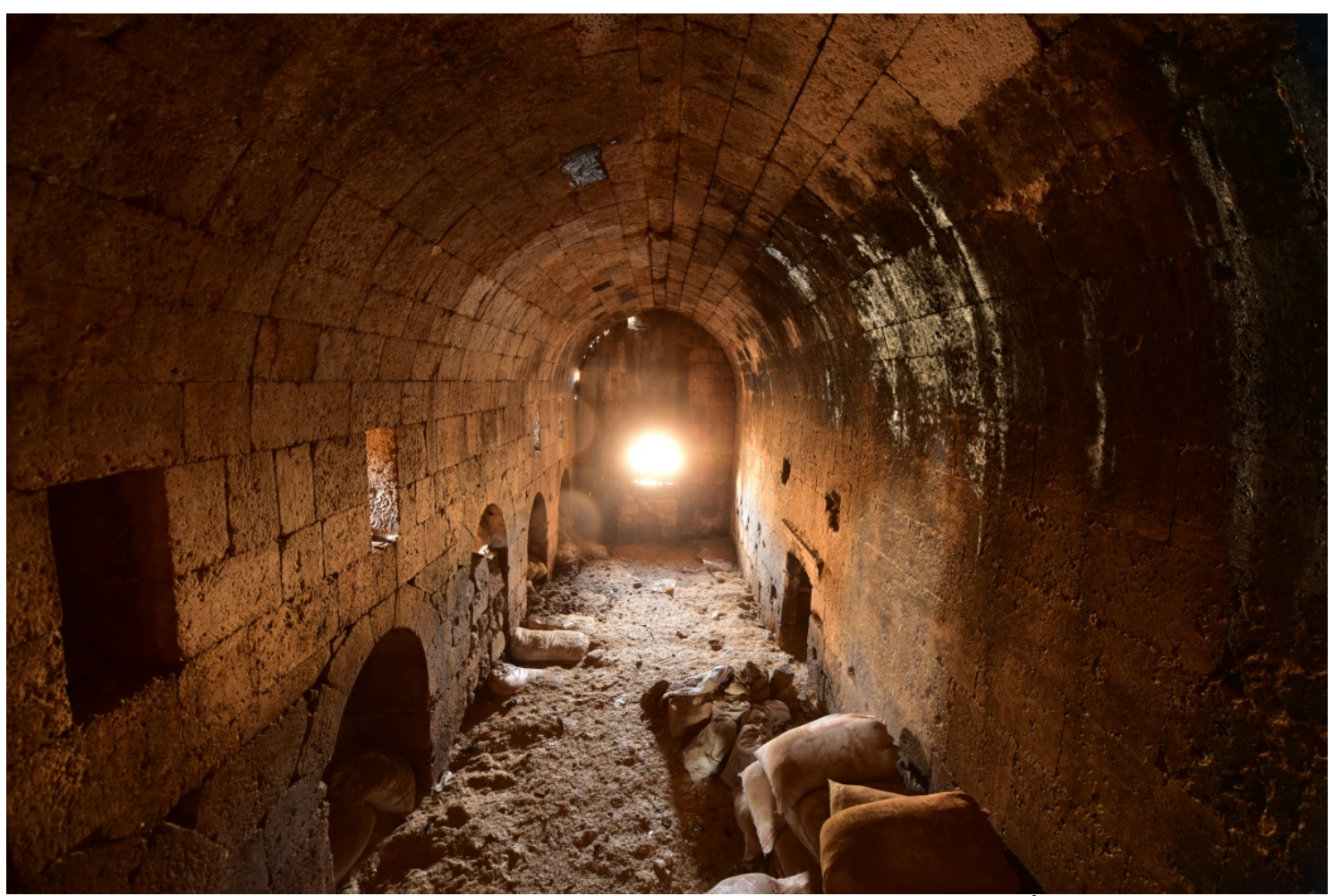

Fot. 16. Nartekse güneyden bakış (Fot. Tehsin BARAVi).

Yapının batısında kuzey-güney doğrultulu uzanan beşik tonoz örtülü dikdörtgen bir alana sahip büyük bir narteks yer almaktadır (Fot. 16). Nartekste, güney, batı ve kuzeyden geçiş sağlayan üç giriş açıklığı vardır. Aydınlatma için küçük Mazgal pencereler kullanılmıştır. Narteksin içinde batı cephe duvarında yuvarlak kemer açıklıklı 
girişin iki yanında yuvarlak kemerli büyük niş bulunmaktadır. Narteksten naosa, doğu cephe duvarındaki açıklıkla giriş sağlanmaktadır.

Yapının çevresini saran köy evlerinden dolayı günümüzde özgün avlusu (atriumu) mevcut değildir. Ancak mimari kalıntı ve izlerden anlaşılmaktadır ki kilisenin batısında, büyük bir ihtimalle, revaklı bir avlusu vardı. Kilisenin batı cephesindeki duvar izleri ve güneybatı köşesinde bulunan taş işçilikli yuvarlak kemerli, yarım kubbe örtülü yazlık şapelin varlığı burada bir avlunun olduğunu düşündürmektedir (Fot. 17). Yörenin sıcak mevsimi de göz önünde bulundurulduğunda burada revaklı bir avlunun olduğu sanılmaktadır. Kilisenin kuzeyinde ise, doğu-batı uzantılı iki birimli tonoz örtülü bir ek bölüm yer almaktadır (Fot. 18). Bu bölümün giriş açıklığı batıdaki lento açıklık ile sağlanmaktadır. Buranın kilisenin ana mekânına girişi bulunmamaktadır

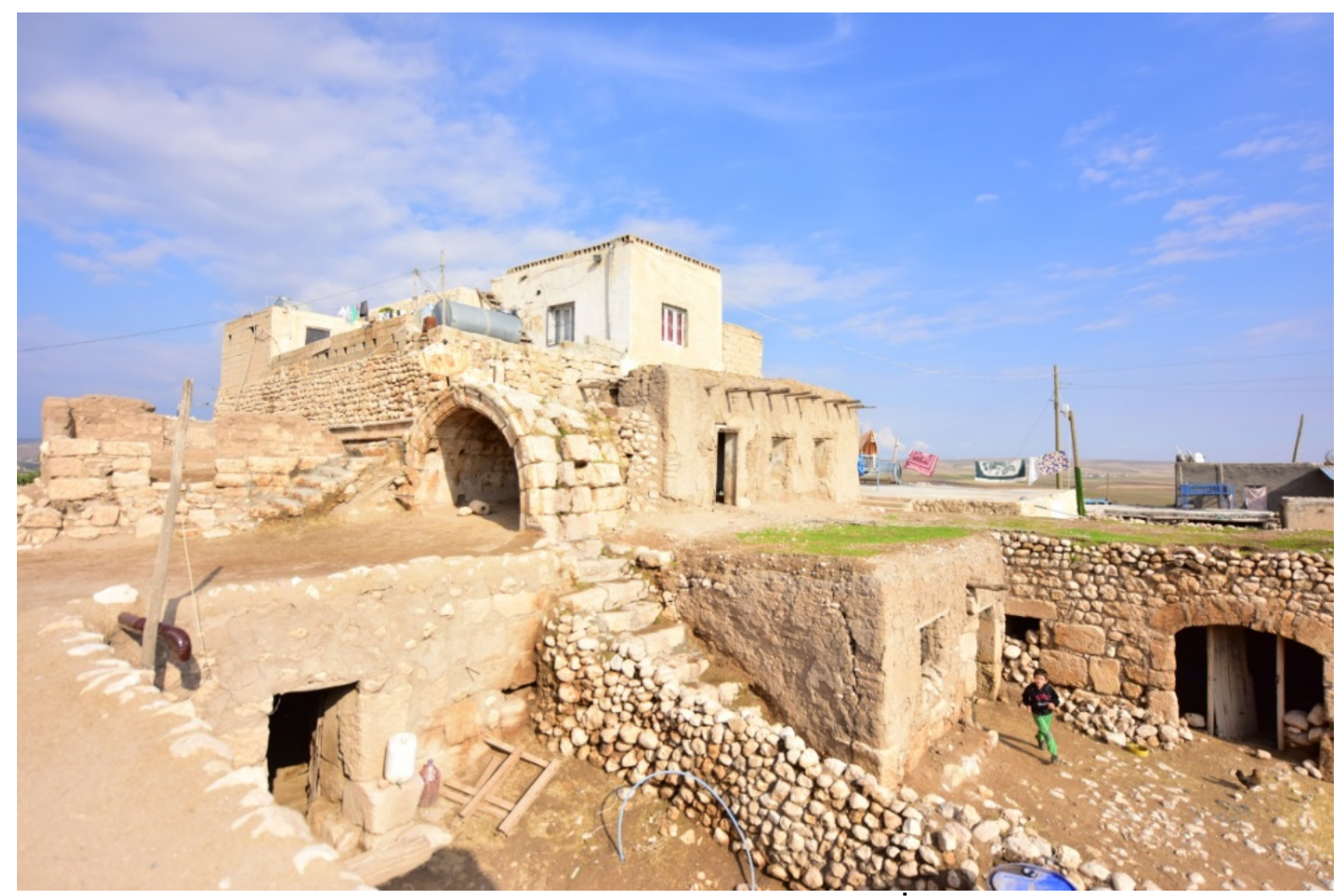

Fot. 17. Kiliseye kuzeybatıdan bakış (Fot.Tehsin BARAVí). 


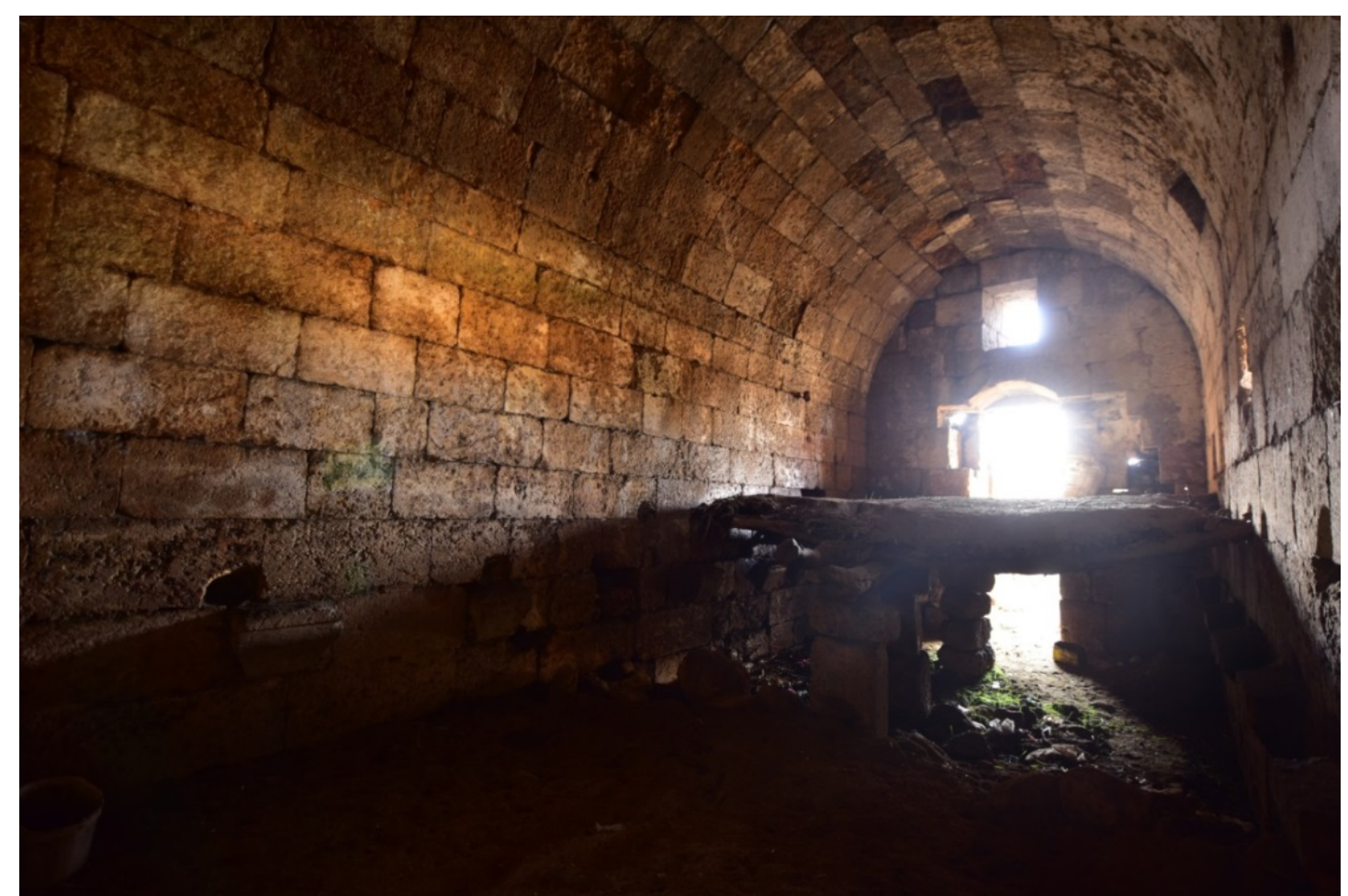

Fot. 18. Kuzeydeki bölümden batıya bakış

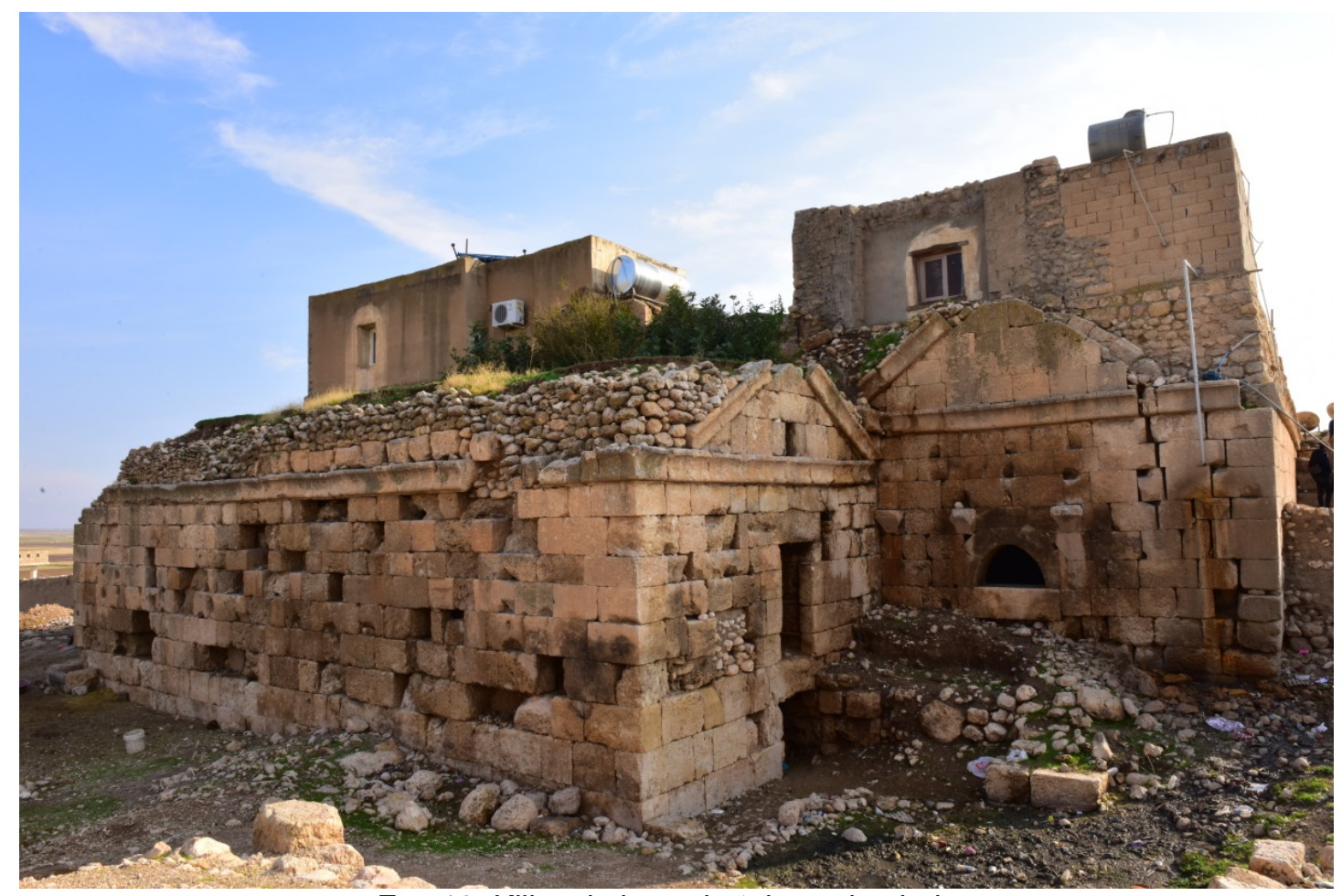

Fot. 19. Kilisenin kuzeybatı köşesine bakış

Bu bölümün batı cephesindeki lento giriş açıklığı ile narteksin kuzeyindeki giriş açıkığı, kilisenin kuzeybatı köşesine açılmaktadır (Fot. 19). Burada zeminde izlenen destek kalıntıları ile duvardaki bingi ve kemer izleri bu köşenin revakı bir ana giriş olabileceğini düşündürmektedir. Nitekim bu cephe Dara Antik kentine bakan ve ovayı izleyebilen bir bakış açısına sahiptir. 


\subsection{Malzeme-Teknik- Süsleme}

Yapım malzemesi yörede sıklıkla kullanılan sarı kalker düz kesme taştır. Kesme taş tekniğinde harçsız örülmüş duvarlar, yapının günümüze kadar gelebilmesini sağlayan dayanıklılıkta bir kalınlığa sahiptir. Duvar örgüsünde kullanılan taş malzemenin örtü sisteminde de devam ettiği görülmektedir. Yapının bütün birimleri beşik tonoz örtülüdür. Kilisenin iç kısmı oldukça sadedir. Naosta ve nartekste bulunan giriş açıklıklarının üzerindeki lentolarda görülen rozetler iç kısımdaki tek süsleme unsurlarıdır. Bunlar da dönem özelliği yansıttığı için önemlidir. Yapının dışı da birkaç uygulama dışında sadedir. En dikkat çeken detay, yazlık şapele (Oratory'e ${ }^{14}$ ) ait kemerde bulunan taş işçiliğidir (Fot. 20). Kilisenin kuzeydoğu köşesindeki birimde yerde bulunan süslemeli taş parçası, yapıdaki süsleme öğelerinden biridir (Fot. 21).Buradaki taş süslemelerin aşınma sonucu silindiği, hasar gördüğü izlenebilmektedir.

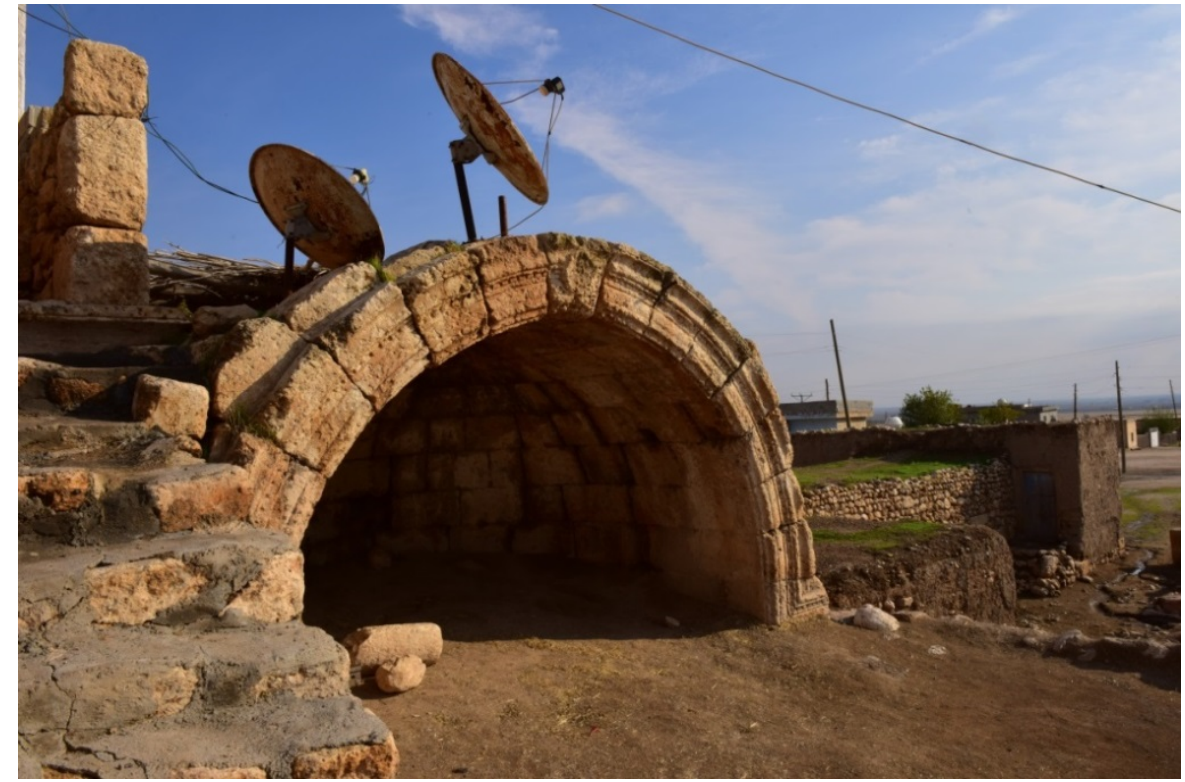

Fot. 20. Kuzeybatıdaki şapele ait kemer.

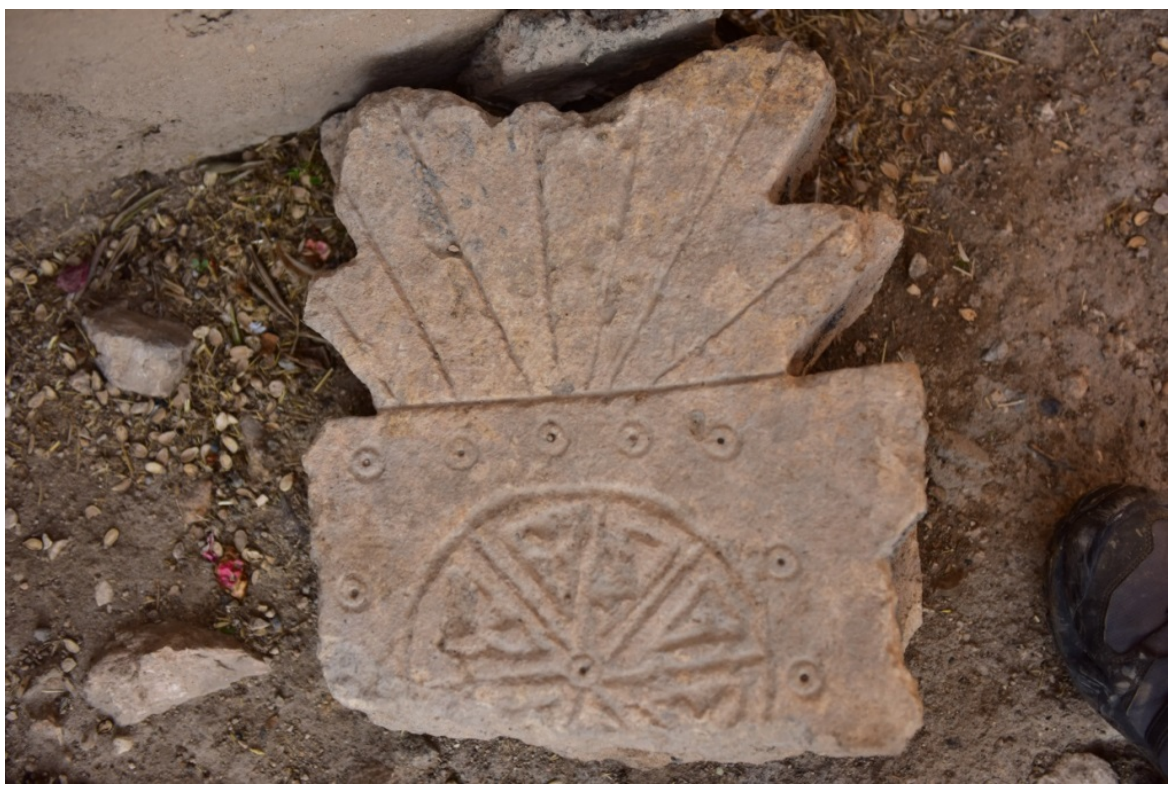

Fot. 21. Süslemeli taş parçası

\footnotetext{
${ }^{14}$ Oratory: özel ibadet için kullanılan küçük şapel.
} 
Araştırmacılar, yazlık bir şapele (Oratory'e) sahip olmasına rağmen bu yapının bir manastır olabileceğine kuşkulu yaklaşmaktadır. Ambar Kilisesi ile ilgili ilk çalışmayı yapan kişi olduğu anlaşılan Mundell, buranın bir cemaat kilisesi olabileceğini savunmaktadır (Mundell, Mango, Marlia, 1982, s. 52; Keser, 2017, s.165) Mardin'de benzerleri bulunan manastır planlı kiliselerin olduğunu ve bu kilisenin de benzer planlı olması nedeniyle buradaki bir banliyö Manastıra ait olabileceğini belirtmektedir. Lillington-Martin (2007), 530 yılındaki Pers-Roma savaşında Ambar tepesinin siper olarak kullanılmasıyla Ambar Köyü Kilisesi'nin askeri bir manastır olabileceğini savunmaktadır. Romalıların Doğu sınırını korumak için Perslerle yaptığı savaşlar için stratejik bir noktada bulunan ve garnizon kent olarak kullanılan Dara'nın kontrolünü elinde tutmanın önemi oldukça fazladır. Ambar tepesinin stratejik konumu Dara'nın kontrolünü sağlamak için avantaj sağlayan bir noktadır (Lillington-Martin, 2007, s.309310). Ambar tepesinin üzerine konumlanmış olmasıyla birlikte kilisenin kale sağlamlığındaki duvarları, anıtsallığı buranın bir manastır yerleşkesi olabileceği fikrini güçlendirmektedir. Nitekim yapının hali hazırdaki durumu, ayakta kalan duvar izleri takip edildiğinde buranın bir yapı kompleksi olduğu açıkça anlaşılmaktadır. Ayakta ve sağlam olan kilisenin çevresinde, daha önce başka yapıların veya birimlerin olduğunu düşündüren kalıntı izleri de mevcuttur. Bu kalıntı izlerinin daha iyi anlaşılabilmesi için detaylı bir temizleme ve kazı çalışmasının yapılması gerekmektedir.

\section{Yapıda Tespit Edilen Korunma Sorunları}

Tarihi yapıların varlığını uzun süre devam ettirebilmeleri için; yapıdaki bozulmaların zamanında tespit edilmesi, tespit edilen hasarların giderilmesine yönelik koruma çalışmalarının yürütülmesi, sürekli bakımlarının yapılması, zayıflayan kısımlarının sağlamlaştırılması gerekmektedir (Ahunbay, 2021, s. 86-87). Ambar Köyü Kilisesi de korunarak uzun yıllar yaşatılması mümkün olan tarihi kültür varlıklarımızdandır. Yapının korunma ve onarım çalışmalarına zaman kaybetmeden başlanılması, mevcut durum tespiti- rölöve, restitüsyon ve restorasyon projelerinin acilen hazırlanması ve uygulamaya geçilmesi gerekmektedir. Bu bakış açısıyla, Ambar Köyü Kilisesi'nde tespit edilen riskli unsurlar ve bunların ortadan kaldırılmasına yönelik görüşler aşağıda maddeler halinde sıralanmıştır.

1. Yapıya en çok zarar veren, üzerine konumlandırılmış evlerdir. Bu evlerde yaşayan insanlar yapının üzerindeki hareketli yüklerdir. Hareketli yükler süreklilik gösterdiği için yapı daha çok risk altındadır. Bu durum yapının yıpranmasını daha da hızlandırmakta ve statik bakımdan dayanıklıığını zorlamaktadır. Acilen yapının bu evlerden arındırılması gerekmektedir (Fot. 22).

2. Bu evlere ait su depoları da yapının üzerindeki önemli risk unsurudur. Su depolarından sızan sular üst örtüden aşağıya doğru duvarlardan akmaktadır. $\mathrm{Bu}$ durum, duvarlarda sürekli bir ıslaklığa ve neme sebep olmaktadır. Taşa nüfuz eden su hem dışta hem de içte yapı bileşeninin bütünlüğünü tehdit etmektedir. Depolardan sızan su dışında, kaplamasız ve korunaksız olan örtü sistemi ve duvarlar, yağışlardan da etkilenmektedir. Yapının maruz kaldığı su ve nem problemini çözmek için öncelikle su depoları kaldırılmalıdır. Daha sonra yapının tüm yüzeyine; teşhis, temizleme, sağlamlaştırma ve plastik onarım, su iticiler ve yüzey koruyucuların kullanılmasıyla "Taş koruma" yöntemi olan araştırma ve uygulama (Zakar ve Eyüpgiller, 2020, s. 117) çalışmaları yapılmalıdır.

3. Yapının üzerinde yeşeren bitkiler, otlar, mantar ve bakteriler, taşın yüzeyinde gözle görülür çözülmeler yaratmıştır. Taşı deforme eden bu mikrobiyolojik ve biyolojik oluşumlar, hem yüzeyde hem de duvar örgüsünde yapıya zarar veren önemli risk unsurlarıdır. Bunların sebep olduğu bozulmaların önüne geçmek için 
temizleme yapılmalı ve kimyasallar (biosidler) kullanılarak bitki oluşumu engellenmelidir.

4. Manastır olduğu düşünülen yerleşkenin şuan yıkılmış olan diğer birimlerinden ve kilisenin duvarlarından koparılan taşların, çevredeki köy evlerinin yapımında kullanıldığı anlaşılmaktadır. Cephe yüzeylerinde ve özellikle kuzey cephede kopan taş izleri görülebilmektedir. Bununla birlikte, yanlış onarım ve orijinal yapı malzemesiyle uyumsuz yeni malzemelerin eklenti olarak kullanımı da yapıya zarar veren müdahalelerdir (Fot. 23). Bu müdahaleler hem taşın bozulmasına hem de yapının estetik değerini yitirmesine sebep olmaktadır. Yapının uyumsuz eklenti malzemelerden arındıııması ve taş kopma veya eksilme tespit edilen noktaların uygun malzeme ile onarılması bozulmayı durdurmaya ve yapının estetik değerine kavuşturulmasına imkân sağlayacaktır. Ayrıca, yaklaşık 1500 yıllık geçmişi ile zamana karşı direnen kilisenin taşlarında; sıcaklık farkı, yağmur, don gibi doğal etmenler nedeniyle zamanla erozyon oluştuğu, aşınma ve parçalanmanın meydana geldiği izlenmektedir. Geçmiş dönemlerde onarım görmediği anlaşılan yapının, zamanın olumsuz etkilerine de maruz bırakııdığı ve yıkılma riski altında olduğu söylenebilir. Yapıya temizleme, sağlamlaştırma, plastik onarım ve koruma gibi müdahaleler acilen yapılmalıdır.

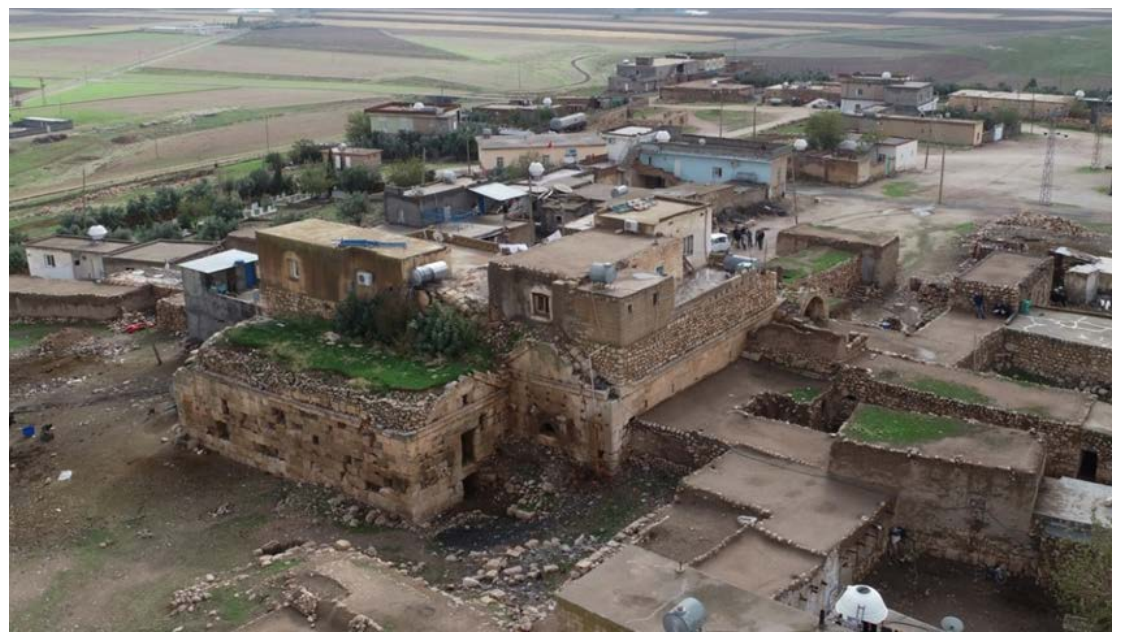

Fot. 22. Kilisenin kuzeybatıdan görünüşü (Fot. Mardin Müzesi Arşivi).

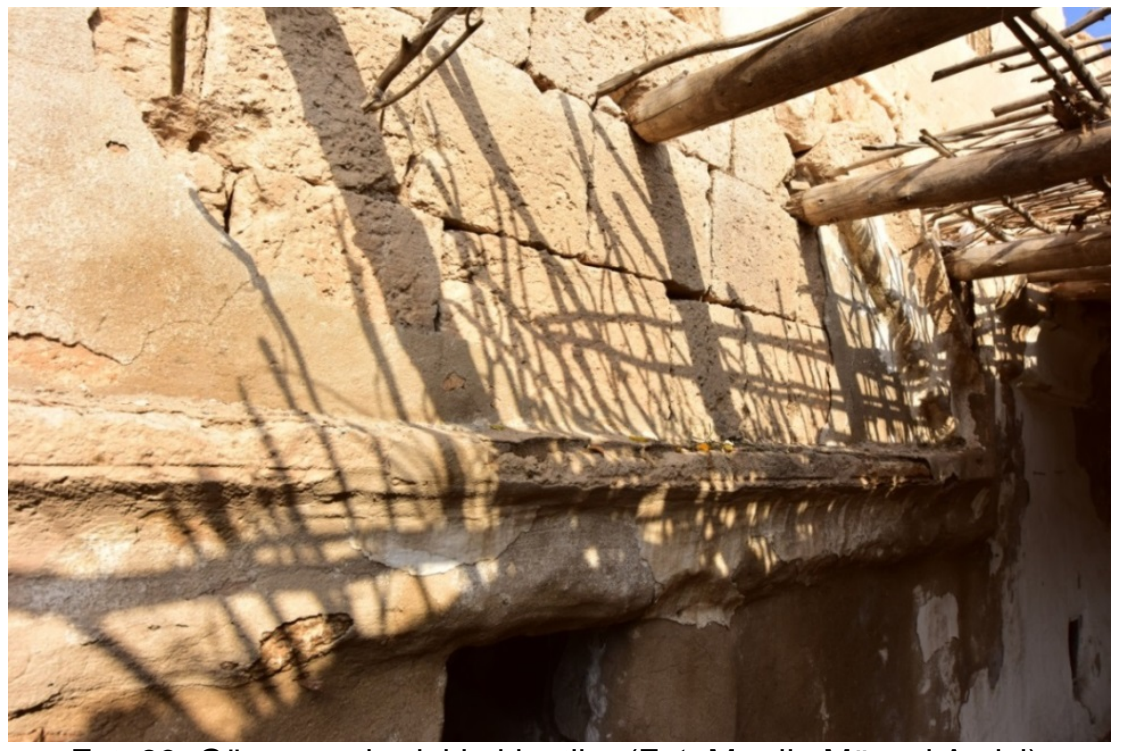

Fot. 23. Güney cephedeki eklentiler (Fot. Mardin Müzesi Arşivi). 


\section{Kilisenin Yeniden İşlevlendirilmesi Önerisi}

Dünyanın önemli ülkelerinden İtalya, Fransa, İngiltere gibi daha birçok ülkenin kültür varlıklarını korumak ve ayakta tutmak için tarihi binalarını, yenilikçi ve çağdaş bir takım öneriler ile gerekli görülen eklemelerle yeniden kullanıma sundukları bilinmektedir. Ülkemizde de çok sayıda tarihi ve kültürel bina, değişen ve gelişen yaşam koşulları karşısında farklı fonksiyonlarla yeniden kullanıcıların hizmetine sunulmaktadır.

Bir yapının yeniden işlevlendirilerek tekrar kullanıma açılması; yapının fiziki dokusunu, tarihi kimliğini, sanatsal yönünü ve kültürel değerini korumaya katkı sunacağı kabul edilen bir gerçektir. Bununla birlikte, hali hazırdaki bir yapının çevresinde yaşayan insanlara; kültürel aktivite imkanı sağlaması, turistik destinasyon noktası olarak kullanılması, yöresel ürünlerin sergilendiği bir mekan imkanı sunması ekonomik açıdan önemli bir katkıdır.

Ambar Köyü incelendiğinde ve köy sakinleriyle görüşüldüğünde ${ }^{15}$; köyün kültürel aktiviteler için kullanabilecekleri bir kamusal mekânının olmadığı, genç nüfusun işsizlik problemi yaşadığı bilgisi alınmıştır. Yörede ekonominin canlandıııması, turizm geliri sağlayabilecek olanakların oluşturulması bir intiyaç olarak ifade edilmiştir. Köyün ortasında bulunan bu yapının turistik cazibe merkezi olabilecek potansiyelinin değerlendirilmesi bu intiyacın karşılanmasını sağlayabilecek niteliktedir. Yöre halkının kullanabileceği yeni bir sosyal mekân oluşturmak ve turizm geliri sağlamak açısından kilisenin yeniden canlandırıması önemlidir. Daha da önemlisi, atıl ve bakımsız halde bulunan kilisenin, tarihi ve kültürel değerine yakışmayan şimdiki durumundan kurtarılması ve yok olmasının önüne geçilerek yapının günümüze kazandırılması gerekmektedir. Taşınmaz kültür mirasımız olan Ambar Köyü Kilisesi tarihi ve dini bir mekândır. Bu özelliğini de kaybettirmeden, uygun bir tasarımla yeniden hayata kazandırıması hem yapının korunmasını hem de yöre halkının ihtiyacının karşılanmasını sağlayacaktır.

Gerekli bakım ve onarımlar yapıldıktan sonra, yapı açığa çıkarılacak ve güncel kullanım için hazır bir bina haline gelebilecektir. Bunun için;

- Kilisenin etrafında yer alan, onu çevreleyen tapulu evlerin kamulaştırılması ve sonrasında bu eklentilerden arındırılması,

- Temizleme ve Kazı çalışması ile yapının orijinal zemininin ortaya çıkarılması,

- Yapının onarım ve bakımının yapılması,

- Aydınlatma, ısıtma ve güvenlik sisteminin sağlanması gerekmektedir.

Yukarıda yapılması gereken çalışmalardan sonra, ortaya çıkan binanın ve birimlerinin restorasyon projesi aşamasında yeni işlevine yönelik öneriler sunulabilir.

Günümüzde değişen yaşam biçimi ve insanların intiyaçları doğrultuşunda, birçok tarihi yapı özgün ve ilk yapılış amacından farklı bir fonksiyonla yeniden uyarlanmaktadır. Bu uyarlama yani yeniden işlevlendirme tarihi yapıları yıkımdan kurtaran bir araç olarak görülmektedir (Ahunbay, 2017, s. 97). Ambar Köyü Kilisesi de ilk kuruluşundaki işlevini yitirmiş durumdadır. Bu nedenle farklı bir fonksiyonla yeniden kullanımı sağlanmalıdır. Çalışmada önerilen yeniden işlevlendirme, öncelikle yapının korunmasına yöneliktir. Bununla birlikte, bu tarihi mekânda uzun yıllardır yaşayan köy sakinlerinin (hane sahipleri, köyün gençleri ve muhtar) istek ve ihtiyaçları da dikkate alınarak yapının güncel bir işlevsellikle yeniden kullanılabilmesi için şu öneriler sunulmuştur.

\footnotetext{
${ }^{15}$ Köyün muhtarı ve yaklaşık 10 hanede bulunan çalışabilecek yaşta bireylerle 13.09 .2017 tarihinde yüz yüze görüşme yapılmıştır.
} 
- Kilisedeki kutsal alanın ve apsis kısmının ikonalarla donatılması ve belli takvimlerde yapılan ibadetler için kullanılabilecek bir mekân olarak düzenlenmesi,

- Ana mekân ile narteks biriminin gösteri ve sergi salonu olarak işlevlendirilmesiyle birlikte, bu iki mekânda duvarlarda bulunan kemerli nişlerin daimi sergi alanı olarak tasarlanarak müze işlevi verilmesi,

- Kuzeydeki iki birimli mekânın, hediyelik eşyaların satıldığı veya aparatif yiyecek ve içeceklerin hazırlanıp sunulduğu bir yeme-içme yeri olarak hizmete açıması,

- Yapının çevresine; gelen ziyaretçilerin gezme-dinlenme gibi intiyaçlarını karşılayabilecek ve köy halkının da kullanabileceği modern bir rekreasyon alanının oluşturulması,

- Dara Antik Kenti ile Kilisenin ilişkisi göz önünde bulundurularak, Dara'nın Turizm yönetim planına dâhil edilmesi önerilmektedir.

Böylece tarih ve sanat tarihi açısından önemli kimliğiyle birlikte ortaya çıkan kilisenin; hem sosyal hem de kültürel bir mekâna dönüştürülebileceği, Dara Antik Kentine gelen ziyaretçilerin uğrayabilecekleri yeni bir turistik destonasyon noktası oluşturulabileceği savunulmaktadır.

\section{Değerlendirme}

Türkiye, tarih boyunca pek çok medeniyete ev sahipliği yapmış kadim bir coğrafyaya sahiptir. Bu medeniyetlerden günümüze gelen mimari kalıntılar veya ayakta kalmayı başarmış mimari yapılar, günümüz Türkiye'sinin değerli hazineleri olarak kabul edilmektedir. Geçmişin açıklanmasında birer belge ve kanıt olarak katkı sunan bu tarihi yapıların korunması, daha uzun süre yaşatılması zorunluluğu doğmaktadır.

Türkiye'deki pek çok il gibi Mardin İli de kadim bir tarihi geçmişe sahiptir. Mardin'de geçmişin hazineleri niteliğinde çeşitli dönemlere ait pek çok mimari yapı: Camiler, medreseler, türbeler, abbaralar, çarşılar, kiliseler, manastırlar bulunmaktadır. Bir kısmı gün yüzüne çıkmış, hayata kazandırılmış yapıların yanı sıra kurtarılmayı bekleyen pek çok yapı mevcuttur. Ambar Köyü Kilisesi de ortaya çıkarılmayı, korunmayı ve yeniden canlandırılmayı bekleyen yapılardan bir tanesi olarak görülmektedir. Dara Antik Kenti ile Ambar Köyü'nün stratejik konumu ve tarihi önemi, söz konusu yapının kültürel değerini gösteren, turizm potansiyelini ortaya çıkarabilecek dinamiklerdir. Bu dinamikler ile kilisenin mimari ve tarihi özellikleri, yörenin kültürel kimliğini yansıtmaktadır. Bu nedenli önemli tarihi bir yapının korunması, çevresiyle organik bağının güçlendirilmesi ve güncel yaşamla bütünleşen uygun bir işlevsellikle yeniden canlandırılması kültürel bir kazanç olacaktır.

Taşınmaz kültür mirası olan kilise, yanına ve üzerine sonradan inşa edilmiş kâgir evlerle iç içe geçmiş durumdadır. Köy konut tipindeki bu eklenti evler, kilisenin tarihi kimliğini gölgeler niteliktedir. Söz konusu evlerde oturan sakinler, kiliseyi ahır ve ambar olarak kullanmaktadır. Kötü ve bilinçsiz kullanım nedeniyle kilisenin tahrip olduğu görülmektedir.

Anıtsal nitelikteki yapı, 6. yüzyıl tarihli Midyat'taki Mor Gabriel Kilisesi (Plan 2) ve Salah'taki Mor Yakup Kilisesiyle (Plan 3) plan tipi ve dış cephe düzenlemesi bakımından benzerlik göstermektedir. Kullanılan malzeme, izlenebilen mimari detaylar ve süsleme öğeleri Ambar Köyü Kilisesi ile Salah Mor Yakup Kilisesinin birbirleriyle çağdaş olduğunu ortaya koymaktadır. Her iki kilisede de cephelerdeki üçgen alınlık, büyük pervaz süslemeler ve narteks giriş açıklıklarındaki kabartma düz (atkı) kemer karakteristiktir ve aynı tarzdadır. 


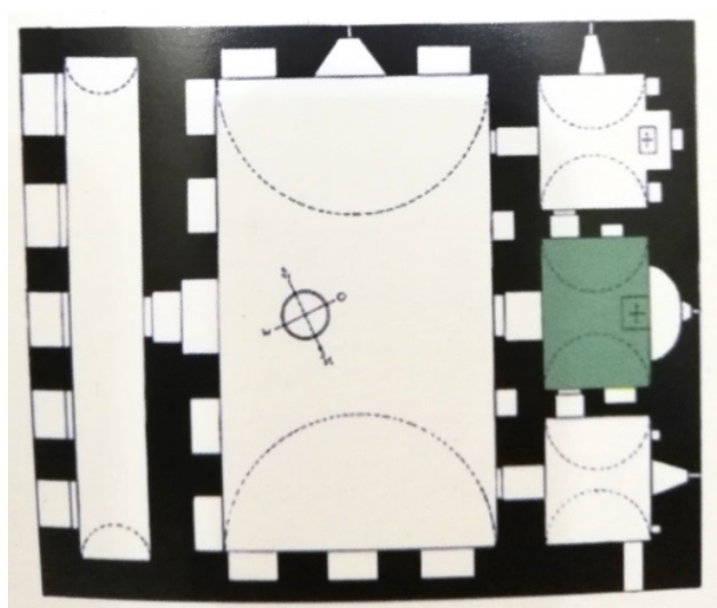

Plan 2. Mor Gabriel Kilisesi (Palmer, 1990)

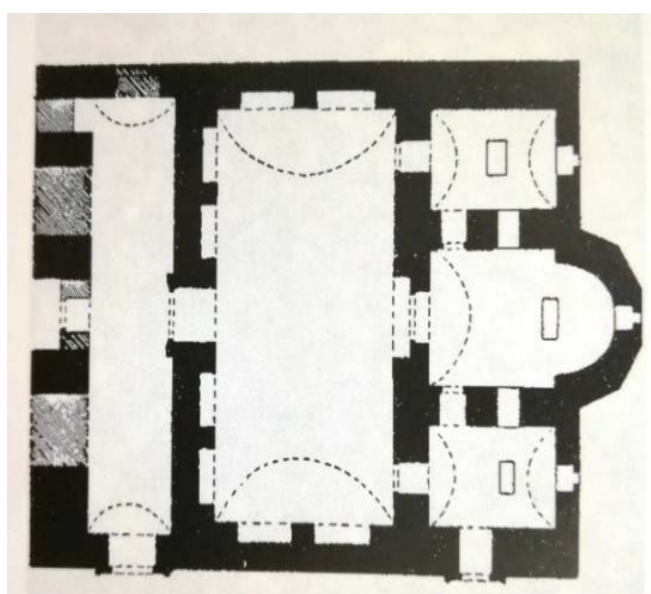

Plan 3. Mor Yakup Kilisesi (G. Bell)

Yapı içte ve dışta sade görünmektedir. Dış cephe kesme taş duvar örgüsüne sahiptir. Kilisenin kuzeybatı köşesindeki anıtsal giriş ile Salah'taki Mor Yakup Kilisesi'nin doğu cephesindeki üçgen alınlık, aynı dönem özelliği taşıyan uygulamalar olarak karşımıza çıkmaktadır (Fot. 24 ve 25).

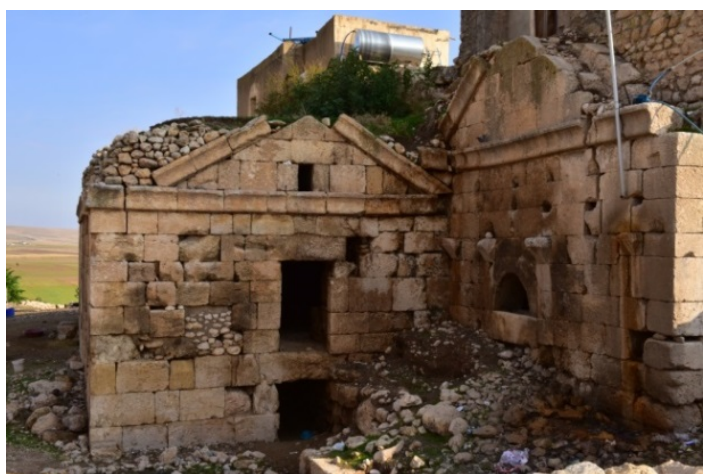

Fot. 24. Ambar Köyü Kilisesi Kuzey Girişi

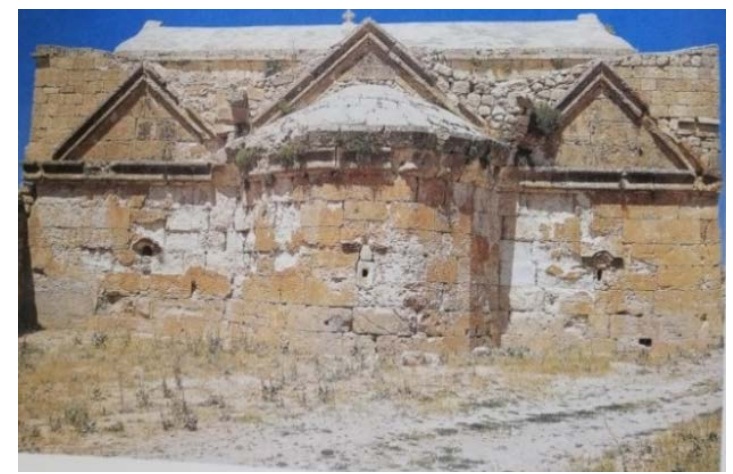

Fot. 25. Salah'taki Mor Yakup Kilisesi

Dara Antik Kenti ile yakın mesafede konumlanmış Ambar Köyü kilisesiyle benzer mimari teknik ve malzeme ile yapılmış tonoz işçiliği ve duvar örgüsündeki uygulamalar da aynı dönem özelliği olarak ele alınabilir. Kilisenin dıştan görünen taş örgülü tonozu ile Dara Antik Kenti'nde bulunan taş örgülü köprülerin işçiliği benzerdir. Kilisenin ana mekân örtüsünde dış kaplaması bulunmayan tonoz, yarım daire formunda blok taş örgülü olup dıştan görünür durumdadır (Fot. 26 ve 27).

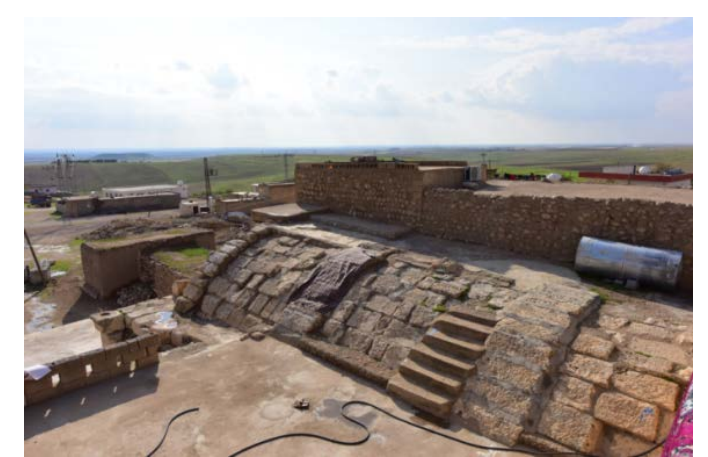

Fot. 26. Kilisenin dıştan tonoz görünüşü

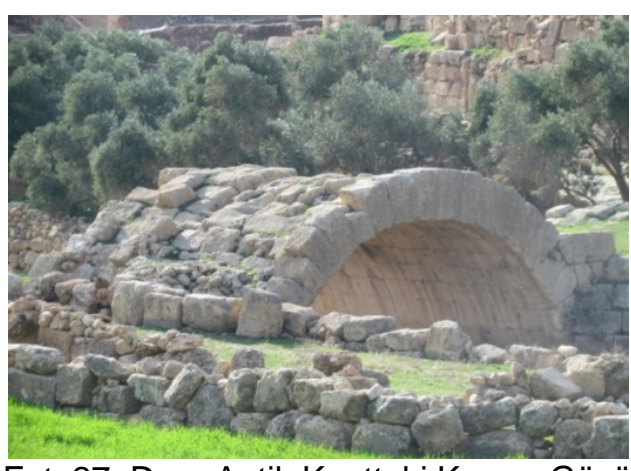

Fot. 27. Dara Antik Kentteki Kemer Gözü 
Konumu itibariyle Dara Antik Kenti'ne yaklaşık üç km kadar yakın mesafede ve kenti gözetlemeye (Mundell'in, 1982, s. 56) imkân veren yüksek bir tepe üzerine konumlanması nedeniyle, güvenliği kontrol altında tutmak için inşa edildiği veya bu amaçla kullanılmış olabileceği düşünülmektedir. Kilise ile Dara'nın yüksek bir ihtimale tarihsel ve stratejik bir bağının olduğu zannedilmektedir. Günümüzde Dara Antik Kenti'nde kazı çalışmaları devam etmektedir. Kazı çalışmalarının tamamlanması daha net bilgiler edinmemize olanak sağlayacaktır. Ancak, hali hazırda ortaya çıkarılmış ve görünür durumda olan kentin dokusu ile kalıntılardan izlenen mimari analizler bile Dara Antik kenti ile Ambar Köyü Kilisesi'nin birbiriyle çağdaş ve ilişkili olduğunu göstermektedir. Bu özelliği sayesinde kilise, Dara Antik Kenti'ni ziyaret edenlerin uğrayabileceği tarihi cazibe noktalarından biri olabilir.

Uzun tarihi geçmişe sahip mimari yapılar, korunduğunda daha da uzun yaşatılabilmektedir. Ancak korunmayan yapılarda zamanla oluşan hasarlar, derinleşmekte ve müdahale edilemez bir boyuta ulaşmaktadır. Bu da yapının yıkılmasına ve yok olmasına sebep olmaktadır. Tarihi mimari varlıklarda yapısal hasara neden olan doğadan (doğa olayları, zemin türü ve yapısı, su ve nem etkisi, biyolojik etkiler ve yangın ) ve insanlardan (yapı geometrisi kusurları, hatalı müdahale, bakımsızıı ve ihmal, çatışma ve yıldırıcı eylemler, yangın, titreşim etkisi, çevre kirliliği) kaynaklı etkenlerin (Vatan-Kaptan, 2019, s. 73) tespiti, risk durumunun belirlenmesi ve zamanında müdahale edilmesi, yapının kurtarılmasında oldukça önemlidir. Dünyanın çeşitli ülkelerinde tarihi yapılardaki tahribatın etkisini azaltmak ve korumak ile ilgili çeşitli çalışmalar yürütülmektedir. Mesela İngiltere ve İskoçya'da "Risk Altındaki Miras" listeleri oluşturulmakta, hor kullanılmış ya da terk edilmiş ve böylece ciddi tahribat ile karşı karşıya kalmış yapılar tespit edilmektedir. Hükümetin bu konuda danışmanlığını yapan yarı bağımsız bir oluşum olan English Heritage ${ }^{16}$ ekibinin yaptığı taramalarla belirlediği risk altındaki yapılar listelenmektedir. Risk altındaki bu yapılar devletin desteğiyle onarılmakta ve yeniden işlevlendirilmektedir (Coşkun, 2018, s. 17-32). Türkiye'de de kültür mirasının korunması ve yönetimi konularında çalışmalar gerçekleştirilmektedir $\left(U R L-2^{17}\right)$. Yapılan çalışmalar umut verici olmakla birlikte, Türkiye'de hala korunması gereken pek çok tarihi mimari yapı bulunmaktadır. Bu yapılardan bir tanesinin de Ambar Köyü kilisesi olduğu düşünülmektedir.

Geçmiş dönemlerde yaşanan savaşlar ve kasıtlı yıkımlar yapıya zarar vermiştir. Fakat günümüzde yapının oldukça hor ve kötü kullanılması nedeniyle yapının daha fazla zarar gördüğü anlaşılmaktadır. Yapıya son derece kapsamlı, yapıyı kurtarmaya odaklanmış süreçlerin uygulanması ve belli aralıklarla bakım ve onarım çalışmalarının gerçekleştirilmesi kültür varlığı olan kilisenin geleceğe güvenle aktarılmasına yardımcı olacaktır. Bu çalışmalar, bilimsel ve çağdaş tekniklere açık, doğru ve güvenilir bilgi yönetimi sentezinden geçirilmiş bir koruma yaklaşımı sergilemelidir. Yapının tahribatını önleyici ve bakım sonrası ortaya çıkabilecek riskleri azaltan projelerinin hazırlanması ve bunların uygulamalarının gerçekleştirilmesi, eserin kültür mirası olarak korunmasını ve yok olma riskinin önüne geçilmesini sağlayacaktır.

\section{Sonuç}

Dara Antik Kenti'nin yakınında bir tepenin üzerine konumlandırılmış Ambar Köyü Kilisesi, Doğu Roma Dönemi inşa tekniği ile yerel plan şemasının birlikte uygulandığı görülen Mardin'deki nadir eserlerdendir. Dara Antik kentine olan konumu ve dönem

\footnotetext{
${ }^{16}$ Ingiltere'nin tarihini anlatan kültür mirasının korunmasına ve bunların sergilenmesine yönelik çalışmalar yapılmaktadır Günümüzde Historic England ismiyle çalışmalarına devam etmektedir (URL-3. https://historicengland.org.uk/ Erişim: 04.04.2021, 15:06)

${ }^{17}$ URL-2. http://www.icorpturkiye.org/Hakkinda.html
} 
özelliği gösteren mimari detayları kilisenin Pers-Roma savaşları zamanında yapıldığını, döneme tanıklık ettiğini göstermektedir.

Tarihi kültür mirasımız olan bu kilise, günümüzde oldukça harap halde ve yıkılma riski altındadır. Alanda gerçekleştirilen gözlemler sonucunda; kilisenin üzerine konumlandırılmış evlerin, bu evlerde yaşayan insanların sebep olduğu tahriplerin, su sızıntılarının, yeşeren bitkilerin, oluşan bakterilerin ve zamanla etkisini gösteren doğa olaylarının meydana getirdiği aşınmaların ve bakımsızlığın, yapıdaki hasarları artıran unsurlar olduğu anlaşılmaktadır. Kilisenin üstünde ve bitişiğinde yapılmış köy evlerinin acilen kamulaştırılması, yapının bunlardan arındırılarak yükünün kaldırılması gerekmektedir. Yapıdaki hasarların ilerlemeden önlenmesi için temizlenmesi, onarılması, sağlamlaştırılması ve yeniden kullanımı yaklaşımı benimsenmelidir. Kilise işleviyle kullanılamaz durumda olan yapının, uygun bir kamusal bina fonksiyonu verilerek, tekrar gündelik hayata kazandırıması faydalı olacaktır. Tarihi cazibesi olan anıtsal nitelikteki kilisenin ibadethane özelliğini de sergileyebilmesi için kutsal alanı belli takvimlerde Hıristiyan cemaatinin ziyaret edebileceği mekan olarak tasarlanması ve diğer birimlerin kamusal bir kompleks yani "Köy Müzesi ve Kültür Merkezi” olabileceği önerilmektedir. Tarihi ve kültürel öneme sahip Ambar Köyü Kilisesi'nin korunması için önerilen yeniden kullanım; bölgenin estetik vizyonunun yeniden formüle edilmesine, karakterli ve tutarlı görsel alanlara dönüştürülerek turizme kazandırmasına imkân sağlayacağı gibi yörenin ve ülkenin ekonomisini de canlandıracağı düşünülmektedir.

\section{Kaynaklar}

Ahunbay, Metin, "Dara-Anastasiopolis", XII. Kazı Sonuçları Toplantısı I, 28 Mayıs-1 Haziran 1990, Ankara Üniversitesi Basımevi, Ankara, 1991, s.391-397.

Ahunbay, Zeynep, Kültür Mirasını Koruma Illke ve Teknikleri, 2. Bs. YEM Yayınları, İstanbul, 2021.

Ahunbay, Zeynep, Tarihi Çevre Koruma ve Restorasyon, YEM Yayınları, İstanbul, 2017.

Akyüz, Gabriel, Mardin İlinin Merkezinde ve Civar Köylerinde ve İlçelerinde Bulunan Kiliselerin ve Manastırların Tarihi, Resim Matbaacılık, İstanbul, 1998.

Aydın, Ayşe ve Şahin, Özer, "Tarihi Yapıların Yeniden İşlevlendirilmesi: Isparta Aya İshotya (Yorgi) Kilisesi'nin Gül Müzesi'ne Dönüşümü", TÜBA-KED 17, 2018, s.63-75.

Bell, Gertrude Lowthian ve Berchem, Max Van ve Strzygowski, Jozef. Amida: II. Kuzey Mezopotamya'nın Eski Hıristiyan Mimarisi, (Çev. Fatih A., Bülent Ö., Hanife T. ve S. Erdem T.), Orient Yayınları, Ankara, 2015.

Bilge, Yakup, 1600 yılık Mor Gabriel Manastırı, GDK Yayınları, İstanbul, 2011.

Birol, Hümeyra, "Birgi Tarihî Yerleşiminin Sürdürülebilir Bir Yaklaşımla Korunmasında Yer Kimliğinin Rolü", IBAD Sosyal Bilimler Dergisi (Özel Sayı), İzmir, 2019, s. 185-197.

Can, Birol ve Erdoğan, Nihat, "Dara, Bizans-Sasani Sınırında Bir Garnizon Kenti ve Kazıları”, Anadolu'nun zirvesinde Türk arkeolojisinin 40 yılı, Ankara, 2014, s. 347-371. 
Coşkun, Burcu. Selcen, "Risk Altındaki Tarihi Yapıların Yeniden İşlevlendirilerek Hayata Döndürülmesi: Astley Castle Örneği”, Tasarım + Kuram, Sayı 25, Mimar Sinan Güzel Sanatlar Üniversitesi, Mimarlık Fakültesi, İstanbul, 2018, s. 17-32.

Güler, Abdülkadir, Mardin Folkloru (Gelenek-Görenek), Marev, İstanbul, 1998.

Günal, Veysi, "Mardin İli'nde Kültürel Turizm Potansiyeli”, Marmara Coğrafya Dergisi, (11), 2005, s.93-124.

Hollerweger, Hans, Turabdin: Canlı Kültür Mirası, Linz,1999.

Işık, Gurbet ve Güneş, Mahsum, "Çok Kültürlülüğün Mirasını Geleceğe Taşımak: Mardin Örneği”, TÜCAUM VIII. Coğrafya Sempozyumu, 2015, s. 449-461.

Keser- Kayaalp, Elif ve Erdoğan, Nihat. "Recent Research on Dara/Anastasiopolis", New Cities In Late Antıquity Documents And Archaeology (Ed. Efthymios Rizos), Cilt: 35, 2017, s. 153-175.

Kütük, Ahmet, Nisibis (Nusaybin), Divan Kitap, İstanbul, 2018.

Lillington-Martin, Christopher, "Archaeological and Ancient Literary Evidence for a Battle near Dara Gap, Turkey, AD 530: Topography, Texts and Trenches", in: BAR S1717, The Late Roman Army in the Near East from Diocletian to the Arab Conquest (Ed. Lewin P. Pellegrini) Oxford, 2007, s. 299-311.

Lillington-Martin, Christopher, "Procopius on the Struggle for Dara in 530 and Rome in 537-38: Reconciling Texts and Landscapes", War and Warfare in Late Antiquity (2 vol), ed. Alexander Sarantis and Neil Christie, Brill, 2013, s. 599- 630.

Mundell, Mango, Marlia "Deux églises de Mésopotamie du Nord: Ambar et Mar Abraham de Kashkar", Cahiers archéologiques. Fin de l'antiquité et Moyen Âge vol. 30, 1982, s. 47-70.

Noyan, Sadettin, 1950, Mardin Ilinin Monografisi, Ankara, 2009.

Özgen, Nurettin, Oçal, Ceylan, "Midyat (Mardin) İlçesinin Kültürel Turizm Potansiyeli", I. Ulusal Coğrafya Sempozyumu Bildirileri, Erzurum, 2012, s. 629-643.

Palmer, Andrew, Monk and Mason on the Tigris Frontier: The Early History of Tur'Abdin, Cambridge University Press, London, 1990.

Uygur, Hatice Kübra, Kültürel Doku İçinde Mardin Süryanilerinin Kutsal Mekan Efsaneleri, Hacettepe Üniversitesi Sosyal Bilimler Enstitüsü, Türk Dili ve Edebiyatı Anabilim Dalı, Türk Halkbilimi Bilim dalı (Basılmamış Doktora Tezi), Ankara, 2015.

Vatan-Kaptan, Meltem, "Miras Alanlarında Risklerin Yönetimi: Afet Öncesi -Sırası Sonrası Yapısal Durum Tespiti”, Kültür Varlıklarına Yönelik Afet Risklerinin Yönetimi, İstanbul, 2019, s. 72-90.

Yeşilbaş, Evindar, "Diyarbakır Çitfe Han'ın Koruma ve Yeniden Kullanım Önerileri”, Mukaddime, 5 (1), Mardin, 2014, s. 65-88. 
Yeşilbaş, Evindar, "Kentsel Koruma Bağlamında Tarihi Mekanların Yeniden İşlevlendirilmesi”, Kent Kültürü ve Kentlilik Bilinci Sempozyumu, Sakarya, 2016, s. 197213.

Zakar, Lory ve Eyüpgiller, K. Kutgün, Mimari Restorasyon Koruma Teknik ve Yöntemleri, İstanbul, 2020.

URL-1. https://www.sabah.com.tr/pazar/2014/06/15/osmanli-sebilleri-eskiden-hayrattisimdi-bufe (Erişim: 08.11.2018, 14:24).

URL-2. http://www.icorpturkiye.org/Hakkinda.html (Erişim: 04.04.2021, 10:50).

URL-3. https://historicengland.org.uk/ Erişim: 04.04.2021, 15:06) 